\title{
Espacio, población y familias en la frontera del Río Cuarto Colonial (Argentina)
}

\author{
María Rosa Carbonari \\ Profesora Asociada \\ Centro de Investigaciones Históricas \\ Universidad Nacional de Río Cuarto Argentina
}

Recibido: marzo de 2014

Aprobado: noviembre de 2014

Resumen: A fines del siglo pasado un cambio historiográfico posibilitó que lo regional dejara de ser entendido como un complemento de la macroestructura. Así, con las fuentes seriales de pequeños espacios del interior, puestos a dialogar con otros documentos, se hilvanaron historias atentas a las complejas relaciones que se fueron construyendo en el juego de las escalas entre lo macro y lo micro. A partir de entonces, no solo se buscó reconocer cuántos eran, sino también visibilizarlos, observando cómo algunos y su familia formaron parte del dominio y otros quedaran dependientes. En ese contexto, para el estudio de la región del Río Cuarto, espacio fronterizo del Imperio español en América, localizada al sur de Córdoba (Argentina), una nueva perspectiva de análisis se configuró a partir de los empadronamientos de 1778,1813 y 1822. Con el seguimiento nominal de los sujetos, se identificaron estrategias de acomodación, de sobrevivencia, cuando no de resistencia y de marginación.

Palabras Claves: Región del Río Cuarto, Frontera, Población, Familias de Elite local, Familias subalternas.

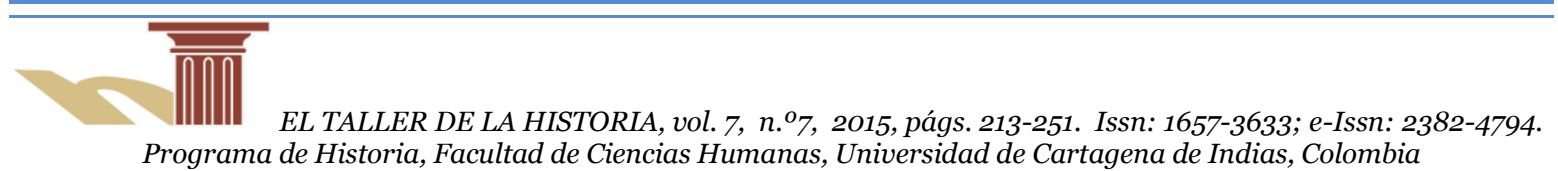




\title{
Space, population and families on the border of the Río Cuarto Colonial (Argentina)
}

\begin{abstract}
In the last century a historiographical change made it possible for regional studies ceased to be understood as a complement to the macrostructure. Thus, with series sources of small interior spaces in dialogue with other records, were constructed stories focusing on the complex relationships involved in the sclaes game between macro and micro. Therefore, we sought to recognize how many there were and make them visible, watching some individuals and their families were part of power and others were in a situation of dependency. In this context, the study of the history of Río Cuarto, space frontier Spanish Empire in America located south of Córdoba (Argentina) opened a new perspective of analysis from the census records of 1778,1813 and 1822 . Therefore, can recognized some adaptation strategies and survival as of resistance and marginalization as used by subjects.
\end{abstract}

Keyword: Region of the Rio Cuarto, Frontier, Population, Families of local Elite, Subaltern Families.

\section{Introducción}

A fines del siglo pasado un cambio historiográfico sustantivo posibilitó que la mirada de lo regional y lo local dejara de ser entendida como un mero complemento de la macroestructura económico-social y las particularidades regionales cuestionaron las limitaciones a las visiones homogeneizantes del estructuralismo. ${ }^{1}$ Con ese

\footnotetext{
${ }^{1}$ Sobre esta problemática, vale considerar una interesante producción historiográfica -de distintos espacios académicos de Argentina- que revela la preocupación por dar estatuto científico a la nueva perspectiva y poner en relieve la importancia de la Historia Regional Susana Bandieri, "La posibilidad operativa de la construcción histórica regional o como contribuir a una historia nacional más complejizada”, en Sandra Fernández y Gabriela Dalla Corte (comps.), Lugares para la Historia. Espacio, Historia Regional e Historia Local en los Estudios Contemporáneos, Rosario, UNR, 2001, María Carbonari, "De cómo explicar la región sin perderse en el intento. Repasando y repensando la Historia Regional", en História Unisinos vol.13, n. ${ }^{\circ}$, Rio Grande do Sul, 2009, pp.19-34. Y las reformulaciones que plantean abandonar la" posibilidad de captar las estructuras y procesos más amplios para explicar acciones, trayectorias y acontecimientos" más bien localizados Francisco Chacón Jiménez, "Familias y sociedad. Reflexión teórica sobre problemas prácticos", en Perfiles de la Cultura Cubana n. ${ }^{\circ}$, La Habana, Revista del Instituto Cubano de Investigación Cultural Juan Merinello, 2012.
}

Dossier: Cuestionando las fuentes de archivos: padrones de población, familias y sociedades coloniales en Iberoamérica, ss. XVIII-XIX 
cambio de perspectiva las fuentes seriales de pequeños espacios del interior puestos a dialogar con otras fuentes cualitativas, cobraron otro sentido colaborando en hilvanar historias atentas a las complejas relaciones que se fueron construyendo en el juego de las escalas entre lo macro y lo micro.

A partir de entonces, no solo se buscó reconocer cuántos eran, sino también visibilizarlos en las diversas coyunturas, observando cómo algunos sujetos formaron parte del dominio colonial y otros se articularon ante el mismo generando distintas estrategias de acomodación, de sobrevivencia y/o de apropiación de los rasgos dominantes, cuando no de resistencia o marginación.

En ese contexto, para el estudio de la historicidad de la región del Río Cuarto, espacio fronterizo del Imperio español en América, localizada al sur de Córdoba, provincia mediterránea de la Argentina, una nueva perspectiva de análisis se configuró sobre las relaciones inter-étnicas atenta a las distintas problemáticas que se fueron dando entre el mundo indio y el hispano-criollo, particularmente presentes en los tratados, interacciones, enfrentamientos y acomodaciones de diverso tipo. Esa línea se ocupó de explicitar y profundizar la conflictividad vinculada al dominio de la tierra entre conquistadores e indios pampas en la etapa colonial y los hispanocriollos (o denominados "cristianos") entre fines del siglo XVIII y fines del XIX, en un proceso que constituyó una larga historia fronteriza de luchas por la apropiación del territorio. ${ }^{2}$

Pero el Río Cuarto, no fue sólo frontera, En el interior del espacio regional de río Cuarto, la invasión de los españoles, con el posterior sojuzgamiento de la población originaria a partir de 1573, implicó una ordenación del mismo y la conformación de una sociedad jerarquizada bajo el control de conquistadores que se distribuyeron la tierra ${ }^{3}$ y la población india. ${ }^{4}$ Así, se reproducía un esquema de dominio y

\footnotetext{
2 En esa línea ver los trabajos de Marcela Tamagnini y Graciana Pérez Zabala, entre los que cabe mencionar "Dinámica territorial y poblacional en el Virreinato del Río de la Plata: indígenas y cristianos en la frontera sur de la gobernación intendencia de Córdoba del Tucumán, 1779-1804”, en Fronteras de la Historia vol.17, n. ${ }^{\circ}$, Bogotá, ICANH, 2012, pp. 195-225.

${ }^{3}$ La propiedad territorial se fue otorgando a "descubridores y pobladores antiguos y sus descendientes” (Tierras Realengas Ley x de 1535. José María Zamora y Coronado, Biblioteca de Legislación ultramarina: En forma de diccionario alfabético tomo 6, Madrid, Imprenta de J. Martín Alegría, 1846, p.38.
}

Dossier: Cuestionando las fuentes de archivos: padrones de población, familias y sociedades coloniales en Iberoamérica, ss. XVIII-XIX 
hegemonía española equivalente a la instalada en los centros mineros, con sus particularidades locales. Lo que implicó la sujeción de la población india, aunque de menor densidad que en otros espacios americanos, a través del régimen de encomienda y el reparto de las tierras a través de mercedes. Ello amparado en la legislación indiana y complementada con la introducción de población esclava que sería mano de obra para las estancias que se localizaron en la región.

En ese sentido, el presente escrito se ocupa de identificar el espacio regional del río cuarto perteneciente a la jurisdicción sur de la ciudad de Córdoba y su articulación con la economía colonial y luego, a partir del estudio de las familias propietarias y otros grupos familiares presentes en los registros censales de 1778, 1813 y 1822,,$^{5}$ analiza cómo las diferencias y desigualdades socio-étnicas operan en el entramado de relaciones que caracterizan a la región.

El espacio regional, aquí sujeto a estudio, no puede considerarse como preestablecido. Por el contrario debe entenderse flexible y dinámico en relación con las transformaciones económicas sociales que llevan continuamente a cortar y recortar el espacio en función de nuevos intereses. El mismo es una espacialidad geográfica con características propias de sierra y de llanura, atravesado por distintos cursos de agua. En función de la apropiación española, puesta en producción y administración, se fueron dando delimitaciones administrativas aproximadas para su control que fueron base para el relevamiento de la población. Dependiente del ámbito de dominio de la ciudad de Córdoba desde su fundación (1573), para su administración religiosa conformó el Curato de Río Cuarto y su anejo (1731) abarcando un importante espacio de la sierra (Comechingones Sur y Calamuchita). La posterior subdivisión del curato (1751) fue repartida internamente para el primer relevamiento censal (1778) y se constituyó la base de las dos jurisdicciones de villas en la campaña fronteriza: Villa de la Concepción y Villa La Carlota, espacio relevado de los registros posteriores (1813 y 1822). Por ello la región es una construcción histórica y sus delimitaciones espaciales se realizaron en función de las actividades eco-

\footnotetext{
${ }^{4}$ La encomienda en cuanto asignación de indios como mano de obra obligatoria para proporcionar servicio a los colonos españoles, fue una institución clave, pues la organización económica y social de América se apoyo en la fuerza de trabajo indígena.

${ }^{5}$ Los tres registros censales se localizan en el Archivo Histórico de la Provincia de Córdoba (AHPC). 1778 Gobierno, caja 18, carpeta 7, El Censo 1813 Serie Gobierno. Ciudad y Campaña, tomo I. El Censo 1822 , en Caja Gobierno.
}

Dossier: Cuestionando las fuentes de archivos: padrones de población, familias y sociedades coloniales en Iberoamérica, ss. XVIII-XIX 
nómicas (establecimientos de haciendas) y eclesiástico (adoctrinamiento religioso) y geopolíticas.

Así explicado el espacio geográfico de la región, interesa reconocer cómo se fueron constituyéndose las relaciones de poder a través de las familias descendientes del fundador de Córdoba, Gerónimo Luis de Cabrera, y los nuevos pobladores españoles que asumieron el control de la región a fines del siglo XVIII. Marco en el cual los grupos dominados, los que debieron constituirse en mano de obra para la economía colonial, debieron adaptarse a esta coyuntura formando parte de la familia colonial ${ }^{6}$ como dependientes agregados o conchabados; conformando familias campesinas bajo una economía de subsistencia; o renegando de todos ellos como marginales del nuevo régimen.

Respecto a los empadronamientos utilizados se presentan las siguientes características sobre el espacio regional. El censo de 1778 fue el primer empadronamiento colectivo de la Colonia. Registró para la ciudad de Córdoba y su jurisdicción 43.511 habitantes y estaba conformada para la época por once curatos o partidos. Uno correspondía a la ciudad y los diez restantes a la campaña, siendo la región rural noroeste de la sierra la más poblada. La región del Río Cuarto, ocupando parte de sierra y llanura, pertenecía a la campaña y representaba $8,5 \%$ de la población de la jurisdicción. ${ }^{7}$ Para la región se registraron 3.720 habitantes. Siendo un censo nominal, la información a censar fue el lugar, la cabecera familiar y los demás dependientes consignando el vínculo parental: hijos, padre, sobrino, etc., con el jefe de la vivienda, así como otros vínculos agregados, conchabado, esclavos, etc., a la

\footnotetext{
${ }^{6}$ La casa se constituye en la unidad familiar básica, allí se registra el propietario, jefe de familia y los dependientes conformando así la familia colonial. Generalmente la composición interna del grupo, estaba representado por el jefe de de casa, su mujer y la progenie socialmente reconocida. Formaban parte de la misma los parientes consanguíneos y biológicos, pero también los que se registraban en relación de dependencia esclavos y sirvientes a semejanza de otros espacios coloniales. Ver al respecto Alida Metcalf, "La familia y la sociedad rural en Sao Paulo: Santana de Parnaíba, 17501850", en Pilar Gonzalbo Aizpuru y Cecilia Rabell (comps.), La familia en el mundo iberoamericano, México, UNAM, 1994, y René Salinas e Igor Goicovic, "Familia y Reproducción Social. Chile en el Siglo XVIII", en Julio Retamal Avila (ed.), Estudios Coloniales vol.I, Santiago, Universidad Andrés Bello, 2000.

${ }^{7}$ Se trabaja aquí a partir de los resultados obtenidos por Dora Celton, La población de la Provincia de Córdoba a fines del siglo XVIII, Buenos Aires, Academia Nacional de Historia, 1993, Ciudad y campaña en la Córdoba colonial, Córdoba, Junta Provincial de Historia de Córdoba. 1996.
}

Dossier: Cuestionando las fuentes de archivos: padrones de población, familias y sociedades coloniales en Iberoamérica, ss. XVIII-XIX 
par la etnia y la edad. ${ }^{8}$ El empadronamiento permite obtener datos acerca de los agrupamientos rurales en parajes o caseríos: tipos de familias: simples o extensas es decir que comparten la misma vivienda más de una generación de casados con hijos, agregados, criados, sirvientes, parientes y esclavos- , familias múltiples - o sea que conviven en la misma unidad habitacional varias familias sin vínculo de parentesco-, posibilita reconocer asimismo las familias más “distinguidas" de ese momento. Nada dice sobre las actividades económicas, si estas familias eran propietarias de tierras o no. Pocas menciones acaso de peones conchabados, y mayor referencia a casos de familias vagabundas o vagabundos solitarios.

El censo de 1813 refiere a la coyuntura iniciada con el proceso independentista. Desde la instalación del gobierno revolucionario de 1810 se vio la necesidad de un levantamiento censal cuyos objetivos eran conocer la población que habitaba el territorio del antiguo Virreinato. El Padrón Censal de 1813 había sido solicitado por la Asamblea General Constituyente de 1813 y en la región fue realizado sobre un recorte diferente al de 1778, puesto que se habían constituido dos Villas de fronteras en la región del llano, teniendo además una finalidad militar, para conformar el ejército revolucionario. Para Córdoba se registro un total de 71.637 habitantes ${ }^{9} \mathrm{y}$ en la región 6115 habitantes. El empadronamiento fue realizado a base de una planilla previamente elaborada. En la misma se consignó en columnas: nombre y apellido de las personas, "patria", edad, estado civil, profesión, clase y condición de libre o esclavo. No se establecieron delimitaciones geográficas por paraje, por eso en el padrón aparecen consignados en forma continua todos los habitantes. Las características de la composición familiar de las unidades habitacionales quedan diluidas. El único criterio geográfico fue la delimitación de las jurisdicciones: Villa de la Concepción, Villa de la Carlota y Fuerte de Santa Catalina. ${ }^{10}$

\footnotetext{
8 Un estudio pormenorizado de empadronamiento censal fue realizado anteriormente María Rosa Carbonari y José Cocilovo. El censo de 1778 en la región del Río Cuarto (Córdoba, Argentina). Fundación Universidad Nacional de Río Cuarto 2004.

9 Datos extraídos de Anibal Arcondo, La población de Córdoba en 1813, Córdoba, Instituto de Economía y Finanzas, 1995, p.32.

${ }_{10} \mathrm{El}$ estudio pormenorizado fue realizado anteriormente sobre este relevamiento Silvia Valdano, María R. Carbonari y José A. Cocilovo, La población de 1813 en la región del Río Cuarto (Córdoba, Argentina), Río Cuarto, UNRC, 2009.
}

Dossier: Cuestionando las fuentes de archivos: padrones de población, familias y sociedades coloniales en Iberoamérica, ss. XVIII-XIX 
El Padrón Censal de 1822 fue a pedido del gobernador de Córdoba, Brigadier General Don Juan Bautista Bustos (1820-1829). Tenía la intención de establecer un sistema electoral en el marco de la autonomía federal. Se registró un total de 6164 pobladores en la región Se identificaron los dos núcleos poblacionales, La Concepción y La Carlota y otros parajes y puestos rurales que antes no se mencionaban. Se mantuvo como modelo la planilla elaborada. En la misma se consignó en columnas: nombre y apellido de las personas, "patria", edad, estado civil, clase y condición jurídica. No se consigna las profesiones ni está discriminado por unidades familiares. Consultado del Archivo Histórico de Córdoba.

El trabajo se estructura en tres partes. Una primera refiere a La identificación del espacio que incluye la cuestión demográfica de la región, y la economía de la región entre fines del siglo XVII e inicios del XIX. Una segunda, trata del control de la región a través de los privilegios de ser "vecinos" de la Villa de la Concepción y las relaciones de poder que se constituyen a través de vínculos familiares. Una tercer parte indaga sobre la recuperación de los sujetos en el mapa regional: diferenciando las Familias de elite y relaciones de parentesco de las otras familias, las familias subalternas, y de los casos de ffamilias "bagamundas", bajo el control de la campaña por familias propietarias por último mostrar un caso particular: el del mulato Bacilio en la región.

\section{La identificación del espacio}

La región del Río Cuarto tuvo su primera delimitación espacial con la constitución del Curato de Río Cuarto (1731) en que incluía una región más amplia de la sierra de Calamuchita, siendo posteriormente subdividido (1751); ${ }^{11}$ división eclesiástica administrativa más austral de la jurisdicción de la ciudad de Córdoba dentro del Imperio Español en América. Esta delimitación abarcaba dos ambientes geomorfológicos diferenciados: la sierra y la llanura, aunque a fines del siglo XVIII, el llano

\footnotetext{
11 Según Juan B. Fassi "[...] A fines de 1749, el [...] Obispo de Córdoba del Tucumán, dispuso la división de los Curatos a través de una línea trazada desde la jurisdicción de la Punta (San Luis), delimitada por La Cruz de José Antonio que debía pasar por San Antonio de El Cano hasta la Dormida del Avestruz. Desde allí, otra línea al S.E. debía pasar por el paraje del zanjón hasta el Saladillo, en el deslinde con Rio Tercero". "El antiguo Curato de Río Cuarto y la Nueva Diócesis", en El Heraldo de Reducción n. ${ }^{\circ} 11$, Córdoba, 1935.
}

Dossier: Cuestionando las fuentes de archivos: padrones de población, familias y sociedades coloniales en Iberoamérica, ss. XVIII-XIX 
pasó a adquirir relativa importancia por constituir parte de la Frontera Sur del Imperio Borbónico en el período Colonial-Tardío. ${ }^{12}$

El relevamiento censal de 1778 dividió internamente esta delimitación en cuatro micro-espacios geográficos que la contenía. Dos en la sierra: Tegua (sierra de las Peñas, donde se localizaba la estancia de Tegua) y Río Arriba (abarcando el espacio de la Estancia San Bartolomé en las sierras Comechingones Sur). Y dos en la llanura: Río Abajo o Parroquia de Río Cuarto (donde se ubicaba la Estancia de Río Cuarto, por entonces herencia de los Cabrera y sede parroquial del Curato) y Frontera del Río Cuarto (donde se había instalado el Fuerte y Presidio Punta del Sauce (1752).

La próxima delimitación fue con la conformación de las dos Villas en 1797, de La Concepción y de La Carlota, interior al Curato, creando dos centros urbanos y otorgándoles a los vecinos descendientes de conquistadores y primeros pobladores el dominio y jurisdicción sobre la región, quedando a los vecinos de Villa de la Concepción del Río Cuarto el control sobre la sierra. ${ }^{13}$

\footnotetext{
${ }^{12} \mathrm{Si}$ bien el espacio geográfico es una aproximación pues las regiones tienen límites, el optar por las delimitaciones que en el período se le dio, posibilita una mejor comprensión de la misma por los documentos que se emanan en dicha época.

${ }^{13}$ En el deslinde de las villas se toma como referencia el curato del Río Cuarto y se constituyeron los siguientes límites: por el Oeste desde la Cruz de San Antonio (Paraje de Achiras), límite con la jurisdicción de San Luis de la Punta al hasta El Cano (arroyo El Cano). Por el Norte: desde San Antonio El Cano, pasando por La Dormida del Avestruz (entre Berrotarán y Almafuerte) en dirección al sudeste debía pasar por el Zanjón del Saladillo hasta topar con una línea imaginaria trazada desde La Esquina o Cruz Alta (perteneciente al curato de Río Tercero) límite para la época con la jurisdicción de Buenos Aires (según lo expresa el plano); hacia el sur sin límite definido, incluyendo El Zapallar o Fortín Loreto (actual Magiolo en Santa Fe), como puntos avanzados (AHPC, Trib. Escribanía Año 1797, leg.52, exp.7). En tal sentido, lo que hoy se constituye en el Departamento de Río Cuarto, es sólo una parte de lo que otrora conformaba el espacio de la región del Río Cuarto.
}

Dossier: Cuestionando las fuentes de archivos: padrones de población, familias y sociedades coloniales en Iberoamérica, ss. XVIII-XIX 
División administrativa aproximada de la jurisdicción de Córdoba

Según el Censo de 1778 a base del mapa actual de la provincia.

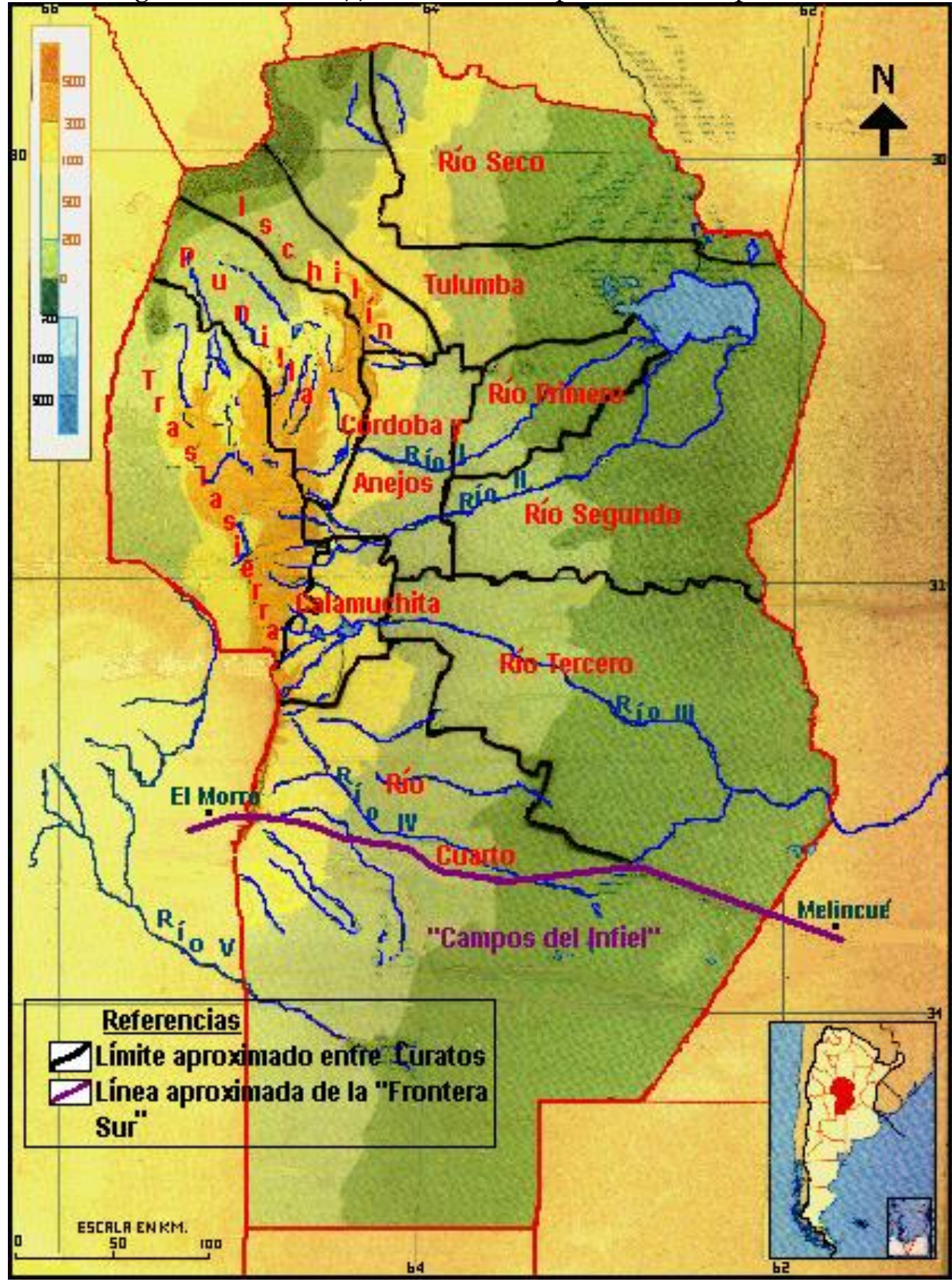

Fuente: elaboración propia en base al mapa actual de la Provincia de Córdoba. 
Jurisdicción aproximada de las villas correspondientes a la Región del Río Cuarto

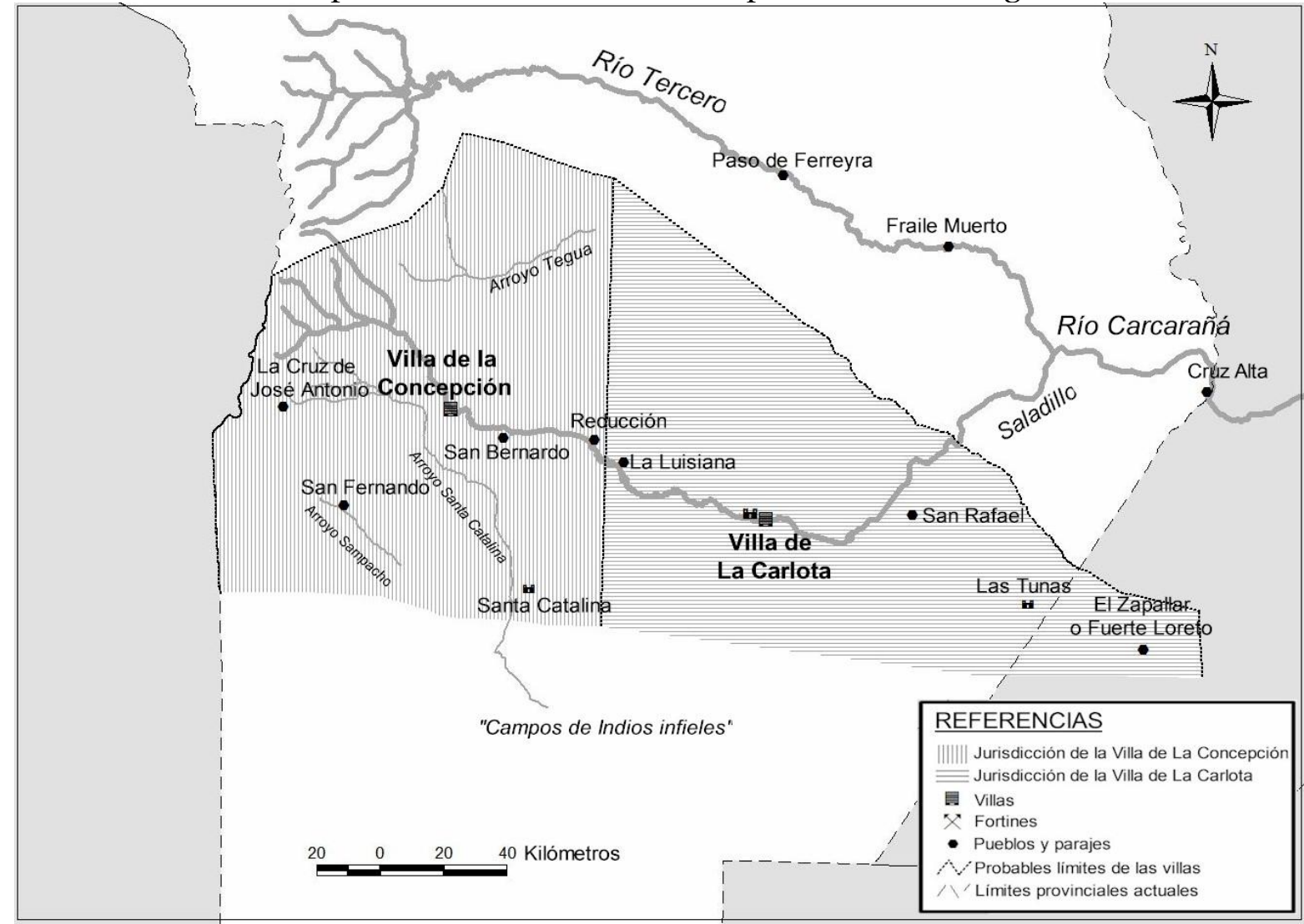

Fuente: Elaboración propia en base al mapa actual de la provincia de Córdoba, tomando los datos del plano de la Frontera Sur de 1797. AHPC, Tribunales, Escribanía Año 1797, leg.52 exp.7. Reproducido también en María R. Carbonari, "La Revolución de Mayo" en una Villa Real de reciente conformación. Diálogo entre lo micro y lo macro", en Miguel Angel Tréspidi y Daila Prado (comp.), Bicentenario, memorias y proyecciones Río Cuarto, UNRC, 2010, p.32. 
De características socio-geográficas diferentes, esta jurisdicción de dominio se constituyó como una franja de articulación entre sierra y llanura pampeana en los confines del imperio, cuyo control efectivo estaba dado por la ocupación de estancias en las márgenes de ríos y arroyos. Esa diferenciación geográfica dejó su impronta en la conformación del espacio social y en la apropiación de los recursos para la economía colonial, tanto de mano de obra como de las actividades productivas desarrolladas. La sierra, con una población india de características sedentarias -aunque poca densidad en relación con otras regiones de Córdoba- y con un tipo de suelo propenso para el desarrollo de actividades vinculadas a la economía colonial, fue la zona más articulada a la economía peruana y por tanto la que mayor desarrollo económico tuvo. La llanura, en la que habitaban grupos étnicos nómadas, mantuvo su independencia del dominio español y en ella sólo se pactaron tratados y negociaciones entre hispano-criollos e indios.

Estas particularidades se vieron reflejadas en la conformación de la frontera y por eso el estudio de la Región del Río Cuarto en la época colonial abarca las dos sub-regiones: a) El de la sierra comechingones sur y sierra las peñas -de antiguo poblamiento-, articulado al espacio cordobés y conectado a la economía potosina; y b) el de la llanura -de poblamiento más reciente-, camino de comunicación entre Buenos Aires, Cuyo y Chile.

Un sub-espacio marginal a la economía colonial que va adquiriendo relevancia por su valor estratégico para el Reformismo Borbónico ${ }^{14}$ y que por ello promueve su interés por poblarlo a través de la fundación de pueblos con la categoría de villa. Política que se apoyaba en ciertas concepciones modernizadoras, pero que también evidenciaban la incapacidad del gobierno por imponer, al menos momentáneamente, su dominio territorial más allá de la región. ${ }^{15}$ Además de que el mode-

\footnotetext{
${ }^{14}$ La política de poblamiento y control llevaron a la instalación de un vallado fronterizo a través de la erección de fuertes y centros urbanos en el camino entre Buenos Aires y Santiago de Chile María Rosa Carbonari, "Población y Espacio. Fines del Siglo XVIII", en Cronía vol.2, n. ${ }^{\circ}{ }_{2}$, Río Cuarto UNRC, 1998.

${ }^{15}$ En el año 1796, el entonces gobernador intendente de Córdoba, Rafael Sobre Monte, formalizó un tratado en la frontera de Córdoba con el cacique ranquel Carripilúm, representado por el cacique Chequelen o Llanquelén, justamente para viabilizar su dominio. Archivo Histórico de Mendoza (AHM) Época Colonial, Secc. Gobierno, Carpeta 42, doc. 35. Ver también Víctor Barrionuevo Imposti, Historia de Río Cuarto, tomo 1, Buenos Aires, TIPENC, 1986, p.88.
}

Dossier: Cuestionando las fuentes de archivos: padrones de población, familias y sociedades coloniales en Iberoamérica, ss. XVIII-XIX 
lo de poblamiento de la frontera respondía a la política borbónica de formación de Nuevas Poblaciones que ya había inaugurado en la propia península Ibérica. ${ }^{16}$

\section{Cuestión demográfica de la región}

Desde la ocupación del territorio al sur de la jurisdicción de la Ciudad de Córdoba, (luego de su fundación) la sierra había sido la zona más valorada económicamente para la producción (mayor asentamiento poblacional indígena que se transformaba en mano de obra y tierras aptas para la economía de ganadería mular) y ello se vio reflejado en la distribución de la población a fines del siglo XviII. La totalidad de la población registrada en 1778 fue de 3720 habitantes (1884 hombres y 1836 mujeres), distribuidos en un área aproximada de $17.109 \mathrm{~km} 2\left(0,22 \mathrm{hab} / \mathrm{km}^{2}\right)$, con cuatro micro-regiones censales. ${ }^{17}$ En ésta, se reproducía la situación poblacional de Hispanoamérica, por la cual la mayoría de los residentes se ubicaban en zonas serranas $(53,3 \%$, frente a la planicie con un $46,7 \%)$. La tabla 1 permite observarlo:

Tabla 1: Región de Río Cuarto, 1778, distribución de la población por sexo y región censal

\begin{tabular}{||l|c|c|c||}
\hline \multirow{2}{*}{\multicolumn{1}{|c|}{ Región }} & \multicolumn{2}{c|}{ Sexo } & \multirow{2}{*}{ Total } \\
\cline { 2 - 3 } & Masculino & Femenino & 638 \\
\hline Sierra Tegua & 334 & 304 & 1343 \\
\hline Sierra Río Arriba & 667 & 676 & 898 \\
\hline Llanura Río Abajo & 446 & 452 & 841 \\
\hline Llanura Río Cuarto Frontera & 439 & 402 & 3720 \\
\hline Total & 1886 & 1834 & \\
\hline
\end{tabular}

Fuente: María Rosa Carbonari y José Cocilovo. El censo de 1778 en la región del Río Cuarto (Córdoba, Argentina). Fundación Universidad Nacional de Río Cuarto 2004.

${ }^{16} \mathrm{El}$ modelo de poblamiento se había iniciado por los borbones en Andalucía que luego extendió a América. Era una política territorial que buscaba colonizar espacios interiores fomentando la creación de centros urbanos en lugares que formaban parte de comunicación entre ciudades.

17 Para un análisis del censo de 1778 en la región ver a M. R. Carbonari y J. Cocilovo. El censo de 1778 en la región del Río Cuarto (Córdoba, Argentina). Existe una transcripción completa del mismo censo (Carbonari, 2003).

Dossier: Cuestionando las fuentes de archivos: padrones de población, familias y sociedades coloniales en Iberoamérica, ss. XVIII-XIX 
En el siguiente registro (1813), en tanto, se contabiliza en la región $6.115^{18}$ pobladores. Respecto a la distribución por espacio geográfico, es decir sierra y llanura, se hace más difícil la comparación entre los dos censos dado que los relevamientos no identifican los lugares de igual modo. La distribución se hace de acuerdo a las jurisdicciones constituidas con las fundaciones de las Villas de la Concepción y de la Carlota, siendo la de la Concepción la que se corresponde en parte con la zona serrana (Río Arriba y Tegua) y en parte menor con la zona de llanura (Río Cuarto Abajo), y la Villa de La Carlota únicamente con la llanura (Río Cuarto frontera o Punta del Sauce). En ese caso, se advierte que el aumento de población del llano puede interpretarse como un indicador de la nueva valorización de ese espacio junto a la decisión política de fundar las dos villas.

Tabla 2: Correspondencia de sectores (1778) con las jurisdicciones de las Villas (1813)

\begin{tabular}{|c|c|c|c|c|}
\hline \multicolumn{2}{|c|}{ Censo de 1778} & \multicolumn{2}{|c|}{ Censo de 1813} & \multirow{2}{*}{$\begin{array}{l}\text { Inc. } \\
\text { (\%) }\end{array}$} \\
\hline Sector & Población & Jurisdicción & Población & \\
\hline $\begin{array}{l}\text { Tegua } \\
\text { Río Arriba } \\
\text { Río Abajo }\end{array}$ & $\begin{array}{c}638 \\
1343 \\
898 \\
\end{array}$ & $\begin{array}{l}\text { Villa La Concepción } \\
\text { Fuerte de Santa } \\
\text { Catalina }\end{array}$ & $\begin{array}{l}4473 \\
158\end{array}$ & \\
\hline Subtotal & 2879 & Subtotal & 4631 & 60,9 \\
\hline $\begin{array}{l}\text { Río Cuarto } \\
\text { (Punta del Sauce) }\end{array}$ & 841 & Villa de La Carlota & 1484 & 76,5 \\
\hline Total & 3720 & Total & 6115 & 64,4 \\
\hline
\end{tabular}

Fuente: Silvia Valdano, María R. Carbonari y José A. Cocilovo, La población de 1813 en la región del Río Cuarto (Córdoba, Argentina), Río Cuarto, UNRC, 2009, p.88.

Según se observa en el registro de 1822, poco había crecido la población en toda la región, pasando a tener 6.158 habitantes. La crisis del Estado Colonial, la ruptura del espacio interior de intercambio afectaba también a la región ${ }^{19}$ y esos factores podrían explicar el estancamiento. Ese relevamiento muestra, también, que el panorama geográfico social de la región había cambiado. La distribución de la población por los parajes o partidos era diferente. En el mismo se mencionan

18 Para un análisis cuantitativo del censo de 1813 ver a S. Valdano, M. R. Carbonari y J. A. Cocilovo, La población de 1813 en la región del Río Cuarto (Córdoba, Argentina).

19 AHPC, Gobierno, 1822 Existe una transcripción paleográfica del Censo de 1822 sobre la región y se han realizado algunos seguimientos cualitativos.

Dossier: Cuestionando las fuentes de archivos: padrones de población, familias y sociedades coloniales en Iberoamérica, ss. XVIII-XIX 
nuevos nombres de lugares que no se registraron en los censos anteriores como el Partido Intiguasi, Achiras, Rodeo Viejo, La Lagunilla y Las Barrancas. Lo que supone una nueva distribución seguramente relacionada con las subdivisiones de las estancias en la zona de la sierra. Así, según el censo, el 56\% de los habitantes se encontraba localizado en la zona de sierra y el $43 \%$ restante en la zona de llanura.

\section{La economía de la región entre fines del siglo XVII e inicios del XIX}

A fines del siglo XVII en La Lagunilla debió haber existido un obraje donde trabajaban esclavos que fabricaban cordellates y frazadas, ya que un expediente de la época así lo menciona, como también hacen referencia a la producción mular en la Estancia de San Bartolomé en la sierras. ${ }^{20}$ En el documento, además, consta que no se había pagado al cura los entierros en la Iglesia del Rio Cuarto, "de los negros que murieron apestados" pertenecientes a las estancias de Don Gerónimo Luis de Cabrera. ${ }^{21}$ Esa fuente revela que entre 1672 y 1683 se habían matriculado para servir de la encomienda y ser adoctrinados entre 18 y 26 esclavos e indios por cada uno de esos años. ${ }^{22}$ Lo que indica cierta dinámica en la economía del área.

Esa referencia permite reconocer, por otro lado, que en el transcurso del siglo XVII la región participaba de los circuitos de la economía colonial y, explotada por los herederos del fundador de Córdoba, contenía una reducción de población

\footnotetext{
${ }^{20}$ Ello se deduce de la deuda que reclama el cura Benegas quien atendía los servicios religiosos de la Estancia: "Tengo recibo [...] quenta lo siguiente, Siete baras de cordellate a diez reales la bara, It quarenta baras de Cordellate a 10 reales la bara, It 5 fresadas a sinco pesos, It mas una piessa de Cordellate de cincuenta V. A diez realez la bara It diez mulas de año que se me dieran en S. Bartolome a 20 reales cavesa”. AHPC, Escribanía 1. Año 1692, leg.175, exp.6. ff.214 y ss.

${ }^{21}$ AHPC, Escribanía 1. Año 1692, leg.175, exp.6. ff.214 y ss. Cabrera debía pagar los gastos a los curas doctrineros, quienes eran los encargados de la evangelización de los indios en encomienda.

22 Por lo que se supone que la población en relación de dependencia de los establecimientos productivos en la región, dependía de la extensión y la existencia de ganado. Se ha calculado que el equipo de las estancias se componía generalmente de un mayordomo y de 2 hasta 20 peones mestizos, indios y esclavos. La estancia de La Lagunilla en Río Cuarto ocupó entre 1672 y 1683 un promedio anual de 22 peones AHPC, Escribanía 1. Año 1692, leg.175, exp.6. ff.214 y ss.
}

Dossier: Cuestionando las fuentes de archivos: padrones de población, familias y sociedades coloniales en Iberoamérica, ss. XVIII-XIX 
originaria junto a población esclava introducida para esos fines. En la documentación también se hace mención a la producción mular que podría vincularse al mercado potosino, un destino con diversos vaivenes que también afectaban a la región. ${ }^{23}$

Pero como se sostuvo anteriormente, desde el inicio de la explotación de las tierras hubo en la región una diferenciación clara entre la zona serrana y el llano. En la sierra una de las principales estancias fue la de San Bartolomé24 que con el correr del tiempo fue escindiéndose entre los herederos de los Cabrera. Primero se constituyeron San Bartolomé, La Tapa y Piedra Blanca, pero una nueva distribución por herencia contemplaba a Las Tapias, Rodeo Viejo, Alpa Corral, Albaricoque, La Cocha y La Aguada. ${ }^{25}$ Las estancias de la región se dedicaban por entonces a la producción ovina y vacuna, aunque en menor proporción a equinos, mulares y caprinos; lo que muestra una producción ganadera diversificada. Por inventarios de bienes de algunos propietarios, puede decirse que hacia fines del siglo XVIII y principios del XIX había además de la producción ganadera una producción textil propia de la región. ${ }^{26}$

La vinculación de la producción de la región del Río Cuarto a la cadena productiva y de comercialización, cuyo destino podría ser el Alto Perú, se hacía a través de comerciantes cordobeses y hacendados - propietarios herederos de conquistadores- de la región. Pero también existía una vinculación con Cuyo que puede verifi-

\footnotetext{
${ }^{23} \mathrm{El}$ comercio mular era el principal ingreso regional y las variaciones de precios tuvieron repercusiones locales. Assadourian muestra esta variación de precios siendo que a inicios del siglo XVII se pagaba por mula entre 56 y 54 reales, pero a fines del siglo XVIII se pagaba 10 reales por mula. Carlos S. Assadourian, Sistema de la economía colonial. Mercado Interno, regiones y espacio económico, México, Nueva Imagen, 1982, p.46.

${ }^{24}$ Esta estancia hacia 1653 se menciona que tenía "mil yeguas de vientre de cría de mulas y 5000 vacas en la campaña y en la sierra" AHPC, Escribanía 1, leg.99. Abarcaba una franja desde el deslinde con Calamuchita al norte hasta el arroyo el Cipión, por el sur. Siendo los límites al oeste la jurisdicción con San Luis y al este, la desembocadura del río Las Barrancas con el Río Cuarto. Ulises D’Andrea y B. Nores, Alpa Corral. Sus orígenes y su historia, Río Cuarto, Córdoba, 2004, p.55.

25 El parcelamiento de la sierra está explicado por U. D’Andrea y B. Nores, Alpa Corral. Sus orígenes y su historia.

${ }^{26}$ Archivo Histórico de la Municipalidad de Río Cuarto (AHMRC), Inventarios de Tasación y Bienes registrados en la Villa de la Concepción. Documentos del Extinto Cabildo de la Villa de la Concepción (1798-1824).
}

Dossier: Cuestionando las fuentes de archivos: padrones de población, familias y sociedades coloniales en Iberoamérica, ss. XVIII-XIX 
carse a través del inventario del hacendado militar Ignacio Soria, propietario de la Estancia de "Sampacha"; localizada en el límite sur entre la jurisdicción de Córdoba y de San Luis de la Punta y en el camino de las pampas. ${ }^{27}$

Por otra parte, en la extensa región del llano había una abundante existencia de ganado cimarrón. Este había sido introducido primeramente desde Chile y Perú pero también desde el litoral. El ganado crecía sin costo y sin inversión de capital.28 Los arreos hacia el norte se nutrían de rodeos cimarrones que se originaron a través de pequeñas manadas que escapaban a la pampa y comenzaban a reproducirse libremente y extenderse por la campaña, hacia tierras con pastos y aguadas naturales. Este ganado era el blanco de las vaquerías. Por eso los vecinos españoles realizaban expediciones organizadas para la caza de ganado que se producía libremente en las pampas con el objeto de extraerles el cuero, el sebo y la grasa.

Hacia inicios del siglo XVII se cuenta con las primeras menciones al vacuno cimarrón en Córdoba cuando el Cabildo refiere a la existencia de vaquerías al sur de la ciudad. A mediados del siglo se plantea, luego, un pleito entre las ciudades de Córdoba y Buenos Aires por el derecho exclusivo de vaquear sobre esas tierras.

El Capitán Joseph de Cabrera y Velazco, ${ }^{29}$ propietario de "Las haciendas, Y posseciones, que tenia En el rio quartto”, explícita que vaquear era una práctica habitual: "[...] Saliendo yo a baquear bacas Simarronas de Las alçadas de dho mi

\footnotetext{
27 Para la economía de la sierra ver Estancia de San Bartolomé. AHMRC, Urbano Echenique Inventario, tasación y partición de sus bienes. Año 180o. Ver la transcripción en Daniela Wagner, La región del Río Cuarto. Una frontera ganadera (fines del siglo XVIII y comienzos del XIX), Río Cuarto, UNRC, 1997. Inédito; para el registro de una estancia en el llano ver Inventario y sucesorios de Don Ignacio Soria sobre Estancia Sampacha. AHPC, Escribanía 1, leg.377 Año 1777, exp.6.

${ }^{28} \mathrm{La}$ inexistencia de costo en el crecimiento de esa enorme reserva ganadera queda expresada en la disputa entre los vecinos Gerónimo Luis de Cabrera y Juan López Fuisa para ser reconocidos como únicos accioneros del ganado cimarrón de Córdoba. Cabrera alega derechos como heredero de su abuelo Hernandarias. Las pretensiones de López Ruisa se basan en los 9.000 vacunos que introdujo en una estancia del Río Tercero en 1644. AHPC, leg.120, exp.3. Citado por C. S. Assadourian, Sistema de la economía colonial. Mercado Interno, regiones y espacio económico, p.31.
}

29 Descendiente del fundador de Córdoba por V Generación, quien hereda la estancia de Río Cuarto junto a la deuda que ésta contrajera.

Dossier: Cuestionando las fuentes de archivos: padrones de población, familias y sociedades coloniales en Iberoamérica, ss. XVIII-XIX 
Padre [...]". ${ }^{30}$ Asimismo, en 1685 el Gobernador de Tucumán otorgó una licencia a otro vecino para sacar veinte mil vacas de las pampas de la provincia del Tucumán. Cabrera, en tanto, opuso en defensa de su derecho a las vacas cimarronas argumentando la escasez del ganado en la zona y su propio derecho a la vaquería en la región. ${ }^{31}$

Puede reconocerse, así, que desde fines del siglo Xviı la región de Río Cuarto estaba bien articulada a la economía colonial, tanto por la producción de ganado mular como por la extracción de ganado vacuno cimarrón. Sin embargo, mientras que el ganado cimarrón se reproducía libremente en las pampas, la mula era un animal doméstico que exigía una mayor dedicación de mano de obra. ${ }^{32}$

Con el transcurrir de los años, se fue dando un agotamiento del ganado cimarrón por lo que paulatinamente se abandonó la práctica de vaquear junto al surgimiento de una nueva forma de explotación del ganado. Desde mediados del siglo XVIII, entonces, la estancia de la época colonial se caracteriza como una unidad de producción dedicada más al ganado diversificado. Así, en la campaña cordobesa en la frontera sur, los españoles hacendados, por la valorización del ganado cimarrón y por el desarrollo de la ganadería mular para el mercado minero, pasaron a ser los "vecinos" más importantes en la región y referentes para la toma de decisiones que orientaban a la economía y también a la política.

Se fue así conformando un espacio rural bajo el dominio de vecinos de la jurisdicción de Córdoba sin que necesariamente habitaran la región. Y, por otro lado,

30 AHPC, Criminal, 1681, exp. 4. Causa seguida por el Cap. Don José de Cabrera y Velasco contra los indios pampas por ataques y amenazas a su integridad física, por robos reiterados y por ayudar a los indios que hacían la guerra en Chile.

${ }^{31}$ Según Cabrera: "será cosa lastimosa que un forastero saque las dichas vacas quitando esta utilidad a las religiones y pobres que hay muchos que en sus Estancias no tienen una vaca y están pereciendo pues la carne es el único sustento en esta tierra". Citado por Aníbal Montes, "Historia Antigua de la ciudad de Río Cuarto", en Revista de la Universidad Nacional de Córdoba vol.xL, n. ${ }^{\circ}$, Córdoba, Universidad Nacional de Córdoba, 1953, p.33) sin referencia al documento.

32 La producción mular "a diferencia del ganado cimarrón que se reproduce de manera libre en las pampas, la mula es un animal doméstico que exige ciertas técnicas, para su reproducción y una especial dedicación en las diferentes etapas que llegan hasta su venta: seleccionar y separar los conjuntos reproductores, ciudad de la alimentación de las pequeñas crías, captar los machos, marcas los animales con hierro, amansarlos...”. C. S. Assadourian, Sistema de la economía colonial. Mercado Interno, regiones y espacio económico, p.42.

Dossier: Cuestionando las fuentes de archivos: padrones de población, familias y sociedades coloniales en Iberoamérica, ss. XVIII-XIX 
otros en relación de dependencia, descendientes de la población originaria, que habitaban anteriormente el espacio o fueron trasladados, conformando la mano de obra para la explotación de las estancias. Allí podría haber algún que otro esclavo o también, por la gran extensión de tierras, alguna población libre dedicada a actividades de autosubsistencia, pero en todo caso fueron más bien empleados esporádicos para las tareas rurales.

En ese contexto muchas de las mujeres campesinas de la región se dedicaban a la producción de tejidos. A fines del siglo XVIII Sobre Monte en el informe sobre la Intendencia de Córdoba del Tucumán ya hacía mención a ello: "El ganado lanar de Córdoba es el principal alivio de la jente pobre [...] producían frazadas, bayetas, ponchos, pellones, alfombras y jergas que se comerciaba con Buenos Aires, Mendoza, Chile, Salta y aún hasta el Perú [...] De los cueros de las ovejas y cabras hacen muy buenos tapetados y cordovanes que tienen el propio jiro". 33 También el comandante de la frontera, Amigorena, en su trayecto de Buenos Aires a Mendoza dejaba registrado la importancia de la producción textil en el sur de Córdoba. Refiriéndose a Tegua decía: "Las mugeres de todos estos Lugares [...] se aplican a hilar y tejer Ponchos". Y afirma lo mismo para Río Arriba Sobre Achiras: "las mugeres se ocupan en su(s) ilados de que tejen Ponchos, Gergas, etc"; y para Posta del Morro: "En todos los Ranchos hay sus Majaditas de Ovejas [...] las mugeres se ocupan de Ilados; pero todas estas gentes son bien pobres sin que se halle un Hacendado de consecuencia”. ${ }^{34}$

La producción textil era la actividad realizada por mujeres en sus propias residencias; allí contaban con majadas de ovejas para la elaboración de la producción artesanal de tejidos. Esta producción generaba cierto excedente que probablemente les permitía a las tejedoras comprar o intercambiar por géneros europeos a comerciantes rurales. Ello se infiere a partir de un Cuaderno de Cuenta y Haberes de un mercader de campaña -1805-1806-. En el documento constan las prácticas mercantiles aplicadas a las familias campesinas para la extracción del excedente en un

\footnotetext{
${ }^{33}$ Rafael Sobre Monte, "Noticias Sobre la Intendencia de Córdoba del Tucumán", en La Revista de Buenos Aires tomo IV, n. ${ }^{\circ} 24$, Buenos Aires, 1861 [1788]. "Noticias Sobre la Intendencia de Córdoba del Tucumán”, en La Revista de Buenos Aires tomo vi, n. ${ }^{\circ}$ 24, Buenos Aires, 1861.

34 Francisco Amigorena, "Descripción de los caminos, pueblos, lugares que hay desde la ciudad de Buenos Aires ala de Mendoza, en el mismo reino", en Cuadernos de Historia Regional vol.Iv, Universidad Nacional de Luján, 1988 [1787], pp.5-33.
}

Dossier: Cuestionando las fuentes de archivos: padrones de población, familias y sociedades coloniales en Iberoamérica, ss. XVIII-XIX 
espacio que se caracterizaba por ser frontera, vía de comunicación y nexo interregional. Estas familias constituían el pilar de las economías rurales y se dedicaban fundamentalmente, en la región de Río Cuarto, a la producción de ganado y de artesanías textiles, actividades de autosubsistencia, cuyos excedentes eran intercambiados por otros productos con el mercader. ${ }^{35}$

\section{Los privilegios de ser "vecinos" de la Villa de la Concepción. Las familias y las relaciones de poder}

Fue por Real Cédula Confirmatoria de la Fundación $(1797)^{36}$ que el Rey Carlos IV les otorgaba a los vecinos propietarios residentes de la región, herederos de conquistadores y primeros pobladores, el poder del ejercicio político, de justicia y de policía en el territorio bajo su dominio.

Así, los vecinos de la Villa se fueron constituyendo a partir de antiguos residentes de la sierra y propietarios herederos de la Merced del fundador de Córdoba, Jerónimo Luis de Cabrera, y nuevos pobladores arribados en el transcurso del siglo XVIII que se emparentaron con sus descendientes por política nupcial. Como es el caso de los Echenique que quedarían con la administración de la Estancia de San Bartolomé en la sierra. Pero a la Villa se habían sumado también nuevos vecinos oriundos de regiones aledañas. Algunos de ellos mantenían vínculos de ascendencia con los Cabrera. Otros habían arribado como militares incentivados por la polí-

\footnotetext{
${ }^{35} \mathrm{El}$ análisis de este documento posibilitó, por un lado, comprender la práctica concreta de un sujeto social, su racionalidad y su estrategia, dentro de un marco de condicionamientos de orden estructural de dominio del capital comercial sobre el de la producción; y por otro lado, reconocer que si bien la economía de la región podría continuar relacionándose al espacio cordobés, su vínculo más directo lo tenía con su espacio interior. También refleja la importancia que podría comenzar a tener el Atlántico e identifica la presencia de la producción textil de la región en manos de las familias campesinas. M. R. Carbonari y R. Magoia, "Prácticas mercantiles y familias campesinas en la región de Río Cuarto a inicios del siglo XIX”.

${ }^{36}$ El Cabildo, como órgano de gobierno de la Villa, debía constituirse con un Alcalde y regidores, quienes, según la legislación española, se transformaban en jueces en primera instancia de causas civiles y criminales que se presentaban ante el Cabildo. Para ejercer estas funciones era requisito ser vecino de la villa: "personas honradas, hábiles y suficientes, que sepan leer y escribir" y preferentemente descendientes de descubridores y primeros pobladores". Ricardo Zorroaquin Becu, La organización política argentina en el período hispánico, Buenos Aires, Ed. Perrot, 1967, p.316.
}

Dossier: Cuestionando las fuentes de archivos: padrones de población, familias y sociedades coloniales en Iberoamérica, ss. XVIII-XIX 
tica de protección de la frontera y luego accederían a tierras fronterizas. Entre ellos los Soria, los Acosta, los López y los Tisera. También arribarían comerciantes españoles interesados por el tráfico con Buenos Aires y Santiago de Chile; como Francisco Paula Claro y Benito del Real de Cadiz, Pedro Fernández de Galicia, por mencionar algunos. Así, en su conjunto, se constituirían en los primeros pobladores de la Villa que asumirían los cargos en el Cabildo. ${ }^{37}$

\section{La recuperación de los sujetos en el mapa regional: Familias de elite y relaciones de parentesco en la región del Río Cuarto en el siglo XVIII}

Las familias propietarias de la región se conformaban, en su mayoría, por descendientes de los conquistadores (Siglo XVI) y primeros pobladores (Siglo XVII y XVIII). Estaban emparentadas entre sí y vinculadas, en diverso grado, al sistema socioeconómico y político del mundo colonial, fundamentalmente cordobés. ${ }^{38}$ El seguimiento nominal de algunos nombres en los registros censales permitió reconocer cómo algunas familias propietarias fueron perdiendo dominio y otras se incorpora-

${ }^{37}$ Los primeros estudios de familias en la región se relacionan con las genealogías de los descendientes de los conquistadores (Arturo Germán de Lascano Colodrero, Linajes de la Gobernación del Tucumán. Los de Córdoba, tomos 1, 2 y 3, Córdoba, Ed. Biffignandi, 1936-1960; Alejandro Moyano Aliaga, Don Gerónimo Luis de Cabrera 1528-1574. Origen y Descendencia, Córdoba, Centro de Estudios Genealógiso de Córdoba, 2003), así como los linajes de los primeros pobladores de la Villa de la Concepción del Río Cuarto y los cabildantes. (Carlos Mayol Laferrère, "Linajes fundadores de la Villa de la Concepción del Río Cuarto. Acosta”, en Boletín del Instituto de Estudios Históricos. Lorenzo Suárez de Figueroa n. ${ }^{\circ}$ I, 1975; "Noticias Histórico-Biográficas de los Primeros Pobladores de la Villa de la Concepción del Río Cuarto", en Boletín del Instituto de Estudios Históricos Lorenzo Suárez de Figueroa, n. ${ }^{\circ}$, 1980 ; "La primera Colonización del Río Cuarto", en Diario Puntal, Río Cuarto, enero 11 de 1981, y El Cabildo y los cabildantes de la Villa de la Concepción del Río Cuarto. 1798-1824, Río Cuarto, UniRio, 2014). A partir de la utilización de registros de bautismo, casamiento y óbito. Adriana Fourcade, Una Villa de Frontera. Estudio de la población de la Villa de la Concepción del Río Cuarto (180o - 1850), Río Cuarto, Ed. Icala, 1991. Y con los censos existentes 1778 , 1813 y 1822, se trató de identificar la relación que espacio y población constituían. M. R. Carbonari, "Población y Espacio. Fines del Siglo XVIII", "Los aportes historiográficos y los estudios de la familia en una región de frontera: Río cuarto a fines del siglo XVIII e inicios del XIX”, en Revista Dos Puntas n. ${ }^{\circ}$, La Serena, San Juan UNRSJ-u, 2009.

${ }^{38}$ En María Rosa Carbonari e Iván Baggini, Población y Familias en la región del Río Cuarto. Fines del siglo XVIII, Río Cuarto, Junta de Historia de la Municipalidad de Río Cuarto, 2004.

Dossier: Cuestionando las fuentes de archivos: padrones de población, familias y sociedades coloniales en Iberoamérica, ss. XVIII-XIX 
ban al pequeño círculo de poder. Con la formación de la Villa, arribaron a la región comerciantes que establecieron vínculo matrimonial con herederas de estancieros de la región y con ello se agregaron a la elite local. Ello se pudo observar a través de las nóminas de quienes integraban las autoridades del Cabildo, cotejado a su vez con el registro censal de 1813 y otros estudios genealógicos.

Los datos suministrados permitieron plantear que a pesar de ser este un espacio fronterizo, inestable y demográficamente débil -comparándolo con otras regiones-, existía en él una sociedad jerarquizada que reproducía los mecanismos propios de una sociedad estamental.

A partir del estudio de una familia en particular, los Acosta, y su participación en el poder local, se identificó el entramado social que se había constituido en este espacio. ${ }^{39}$ Asimismo, la historia de Don Bruno Malbrán y Muñoz permitió plantear cómo un sujeto portador de determinada ascendencia española accedía a cierto reconocimiento social entre pares al arribar a este espacio cuando se le otorga la jerarquía de Villa al poblado. ${ }^{40}$ En ese sentido, los vínculos parentales con las familias propietarias se constituyeron en claves para quienes como comerciantes se sumaban a la villa, ${ }^{41}$ por cuanto los acercaba al poder político al integrarse con la "porción más noble de su onrrado becindario". ${ }^{2}$

\footnotetext{
39 El tronco de esta familia se inició con el arribo de Francisco de Acosta, procedente de Cádiz, a Córdoba, a inicios del siglo XVIII, quien luego pasó a la región de Calamuchita como capitán de milicias y propietario de tierras. Sus descendientes (desde la III generación) conformaron una de las familias más significativas de la sociedad y a través de vínculos parentales y de lazos de vecindad detentaron el poder en la villa. Ese ejercicio de poder se estableció desde el Cabildo y la milicia. María Ester Bordese, Ana Belén Mitre y Gabriel Germanetto, "Poder y red familiar en la Villa de la concepción entre 1798- 1820 (Un estudio de caso)", en Cronía vol.4, n. ${ }^{\circ}$ 2, Río Cuarto, UNRC, 20012002.
}

$40 \mathrm{Su}$ procedencia hispánica, sumada a su cargo de administrador de la Corona, le favoreció en su inclusión a las redes parentales de la región, fortaleciendo así los nexos sociales en la villa. Nancy Falco y Susana Negro, "Don Bruno Malbrán y Muñoz y su incorporación a la red de familias de la elite de la Villa de la Concepción”, Córdoba, UNRC, 2009. Inédito.

41 Don Bruno integró rápidamente el círculo de vecinos notables, participó o estuvo próximo a ello, en el gobierno de la Villa, particularmente en la coyuntura de ruptura del orden colonial e inicios de la etapa independentista, si bien debió contribuir por "español" a la causa "patriótica". Pasada la revolución porteña y la tensión entre españoles y criollos en la villa, don Bruno Malbrán y Muñoz se transformó en autoridad local, obteniendo el cargo de alcalde. En el transcurso de ese tiempo conservó el reconocimiento y además aumentó su patrimonio económico. Asimismo, parte de su des-

Dossier: Cuestionando las fuentes de archivos: padrones de población, familias y sociedades coloniales en Iberoamérica, ss. XVIII-XIX 
Así, la red de relaciones se conformó con base a intereses comunes. Es decir, el de sostener la propiedad de las tierras y las haciendas en la serranía o en el llano, vincularse al comercio que se situaba en el "tránsito preciso" y conformar los espacios de poder de decisión local. De modo que se producía una especie de endogamia social y geográfica entre las familias propietarias y el poder político configurado por los lazos de parentesco y vecindad, según puede visualizarse a través de los testamentos, inventarios y estudios genealógicos realizados.

\section{Las otras familias, las familias "subalternas"}

Pero las familias propietarias que conformaban la elite regional y en algunos casos el poder local del Cabildo no solo tenían estrategias de alianzas matrimoniales y practicaban lazos de solidaridad vecinal. También mantenían en sus hogares, en relación de subordinación, a otros individuos identificados en el censo de $1778 \mathrm{co-}$ mo agregados, conchavados, esclavos o peones. Toda una población subalterna 43 que, al estar registrada en relación de dependencia al amo o al jefe de la familia, no siempre puede individualizarse por sus propios vínculos de parentesco o identidad.

Sobre algunos de estos sujetos, no obstante, es posible construir parte de sus lazos a partir de otros vestigios, aunque sea de forma parcial y fragmentada. Por lo visto, pertenecían a familias de campesinos, de labradores o eran excluidos de la economía y sociedad colonial. Sus prácticas culturales y sus estrategias de sobrevi-

cendencia familiar mantuvo luego las mismas estrategias matrimoniales para su reproducción en la elite de la región del Río Cuarto en la primera mitad del siglo XIX. N. Falco y S. Negro, "Don Bruno Malbrán y Muñoz y su incorporación a la red de familias de la elite de la Villa de la Concepción"

42 Según las Acta del Cabildo de la Villa de la Concepción del Río Cuarto del 11 de agosto de 1810. María R. Carbonari, "La Revolución de Mayo" en una Villa Real de reciente conformación. Diálogo entre lo micro y lo macro", en Miguel Angel Tréspidi y Daila Prado (comp.), Bicentenario, memorias y proyecciones Río Cuarto, UNRC, 2010. Ver también Actas capitulares de la Villa de la Concepción de Rio Cuarto, (1789-1824), Buenos Aires, Academia Nacional de Historia, 1947.

43 Como bien ha sostenido Gramsci, "la historia de los grupos sociales subalternos es necesariamente disgregada y episódica", siendo que los grupos subalternos sufren siempre la iniciativa de los grupos dominantes" Antonio Gramsci, Cuaderno de Cárcel. Tomo II, México, Ediciones Era, 1981 Cuaderno 3 (XX), 10 bis, p.27.

Dossier: Cuestionando las fuentes de archivos: padrones de población, familias y sociedades coloniales en Iberoamérica, ss. XVIII-XIX 
vencia los ubican en el mundo rural fronterizo de la región de Río Cuarto durante el siglo XVIII y principios del siglo XIX.

Muchas de esas familias eran españolas pobres pero la mayoría formaba parte del cruzamiento de grupos étnicos entre españoles pobres, indios y negros que constituían más de la mitad de la población ( $51 \%$ en 1778 y $52 \%$ en 1813 ).

En la región, cuando se dio el proceso de fraccionamiento de tierras que facilitó el poblamiento de la segundad mitad del siglo XVIII, de las 22 escrituras estudiadas por Mayol Laferrere solo siete correspondían a individuos que llevaban la partícula de "don”. Es decir, de un símbolo de distinción y diferenciación social para la época. Así, se infiere que los protagonistas de las escrituras eran miembros de familias sin ascendencia de conquistadores. Aquellos que accedieron a terrenos en un momento en que las tierras necesitaban ser ocupadas, independientemente de su valor.

Uno de ellos fue Mateo Cabral, "mulato" residente de Río Segundo. ${ }^{44}$ Cabral en 1758 compró tierras que habían pertenecido primero al Convento de Santa Catalina de Sena y luego a Santiago Moreira por un valor de 30 \$. En un censo eclesiástico levantado en 1773, Mateo Cabral es registrado con su familia integrada por 14 miembros. ${ }^{45}$ Posteriormente en 1778 es anotado como viudo, con 5 hijos, más 5 agregados de apellido Moyano y Flores. Colindante a su casa fue registrado uno de sus hijos: Mariano. ${ }^{46}$ En otro documento los hijos de Mateo, Joseph Mariano Cabral e Joseph Antonio, figuran entre los propietarios que donan terrenos para la construcción de la villa de La Concepción. ${ }^{47}$ Lo que posibilitó que en el reparto de solares le adjudicaran a Joseph Mariano un terreno junto a su mujer, 4 hijas y 4 hijos; a Joseph Mateo -viudo con dos hijos y 70 cabezas de ganado- dos sitios; y a

\footnotetext{
${ }^{44}$ AHMRC, Período Colonial. Carpeta n. ${ }^{\circ}{ }^{1}$. (antes de 1798)

45 Este censo es una lista de individuos registrados con el número de sus familias que fue parte del resumen mandado a levantar con motivo del traslado del cura párroco de Río Cuarto al Tambo. Extraído de la Colección Mons. Cabrera. Se encuentra una copia del mismo en el Archivo del Seminario Mayor Buen Pastor. Río Cuarto.

46 Casa n. ${ }^{\circ} 111$ en Censo 1778 María R. Carbonari, Censo 1778. Partido de Río Cuarto, Río Cuarto, UNRC, 2003, p.36

${ }^{47}$ Expediente sobre la Fundación de Río Cuarto. AHPC, Tribunales 1, leg.52, exp.7, 1797.
} 
Joseph Antonio, registrado con una hija, tres esclavos y dos agregados, un sitio. Uno de estos agregados, Bernardo Flores, en 1778 también obtuvo una parcela de tierra. ${ }^{48}$ Posteriormente, uno de los descendientes del mulato Mateo Cabral, Joseph Mateo, se localiza en el año 1813 registrado como "español" hacendado, junto a dos hijos. Uno, de profesión hacendado y, el otro, de peón en la jurisdicción de La Carlota, como labrador mestizo, contando con 6 esclavos.

Si bien los Cabral habían adquirido propiedades, entre sus descendientes no se encuentra ninguno que haya accedido a cargo político, privilegio de los vecinos primeros pobladores. Por lo que puede inferirse que aunque en el ámbito rural las diferencias entre los grupos no tenían las barreras del control social que se ejercía en las ciudades, ${ }^{49}$ los límites étnicos-sociales estaban igualmente instalados. En la documentación consultada, el caso de la familia Cabral puede ser el más expuesto, si bien es posible que otras familias identificadas indistintamente como pardas o mulatas (según el registro) libres hayan conseguido ser propietarias de tierras y de esclavos, aunque no asumieran la condición de vecinos y por tanto a la posibilidad de acceder a cargos políticos.

En otro caso, el de la familia mulata "de la Mar," se registra en el censo de 1778 en cinco casas colindantes. ${ }^{50} \mathrm{En}$ el año 1794 parte de esta familia adquiere terrenos en la Villa, mientras Francisco de La Mar y Rudecinda de La Mar, mujer de Francisco Campero y dos hermanas, se habían trasladado al paraje San Bernardo posiblemente acompañando a sus maridos. La familia de Rudecinda negociaba con Cayetano Proni, el comerciante que se mencionara anteriormente. En otros documentos contables del año 1805 se anota que "Redusinda de la Mar con su hija Rosa Campero tomó una fuente marca menor en dos pesos mas siete y media baras

\footnotetext{
48 Existe también el Inventario, tasación y partición de bienes de Bernardo Flores AHMRC, Fondo documental del Extinguido Cabildo de la Villa de la Concepción del Río Cuarto. 16-06 180o. Caja 6 exp. 936 fojas.

${ }^{49}$ Como Endrek lo comenta para toda la campaña cordobesa. Emiliano Endrek, "El mestizaje en Córdoba. Siglo XVIII y principios del XIX”, en Cuadernos de Historia n. ${ }^{\circ}$ XXXII, Córdoba, UNC, 1966

50 Casas n. ${ }^{\text {os }} 162,163,170,171$ e 172. M. R. Carbonari, Censo 1778. Partido de Río Cuarto, pp.4445).
}

Dossier: Cuestionando las fuentes de archivos: padrones de población, familias y sociedades coloniales en Iberoamérica, ss. XVIII-XIX 
de paño de seda a seys pesos barra mas un sombrero en tres pesos". ${ }^{51}$ Por lo visto, el comerciante les vendía productos europeos a las familias campesinas a través de trueques o intercambios que eran los dinamizadores de la economía de la época. ${ }^{52}$ Para el año 1813, en tanto, los de la Mar fueron registrados como "pardos", de profesión labradores los hombres y tejedoras o hilanderas las mujeres.

Otro protagonista de los registros de la región es Luis de Cabrera, "pardo livre", quien también había comprado tierras a mediados del siglo XVIII. En 1778 es identificado como "mulato" junto a sus siete hijos. En 1794, el mayor de sus hijos, Joseph Isidoro, fue censado junto a su mujer en el paraje de San Bernardo. Para 1813 se desempeñaba como peón y su mujer como tejedora, con siete hijos. Dos anotados como labradores, una de sus hijas como tejedora y la otra costurera. En todos los casos identificados como pardos libres.

Estos grupos de familias calificadas como mulatas o pardas revelan que, junto a las familias de españoles propietarios que conformaban la elite regional y mantenían el dominio político y social, existían otras que también fueron ocupando tierras mientras se dedicaban a las tareas rurales. Lo que les permitió, en algunos casos, adquirir parcelas y llegar, incluso, a ser propietarias de esclavos.

Garavaglia ha planteado que en la América hispana desde mediados del siglo XVIII, y con variantes, es perceptible el lento surgimiento de un campesinado fuertemente mestizado y jurídicamente libre. En la región del Tucumán y en el siglo $\mathrm{XVIII}^{53}$ es posible encontrarlo en casos que así lo corroboran. En tal sentido, en estas

\footnotetext{
51 Libro de Cuentas y Haberes de Cayetano Proni. M. R. Carbonari y R. Magoia, "Prácticas mercantiles y familias campesinas en la región de Río Cuarto a inicios del siglo XIX”.

52 M. R. Carbonari y R. Magoia, "Prácticas mercantiles y familias campesinas en la región de Río Cuarto a inicios del siglo XIX".

53 Estos habrían surgido de horizontes bastantes diversos: familias indígenas que habrían abandonado los pueblos indios; blancos empobrecidos cuyo medio de subsistencia era la roza de una pequeña parcela y el trabajo de los miembros de la familia en diversas ocupaciones; y mulatos y pardos libres a los que se les agregarían individuos migrantes de distintas regiones del espacio rioplatense (paraguayos, altoperuanos, pampas en proceso de araucanización, entre otros. Para Garavaglia la jurisdicción de Córdoba y Tucumán en el transcurso del siglo XVIII presentaba las áreas demográficas más densas. Juan Carlos Garavaglia, "Los textiles de la tierra en el contexto colonial rioplatense: ¿una revolución industrial fallida?”, En Anuarios IEHS n. ${ }^{\circ}$, Tandil, Universidad Nacional del Centro de la Provincia de Buenos Aires, 1986, pp.58-59.
}

Dossier: Cuestionando las fuentes de archivos: padrones de población, familias y sociedades coloniales en Iberoamérica, ss. XVIII-XIX 
tierras, por ejemplo de la sierra, se registran familias mestizas, en tanto en la llanura se las denomina hispano-criollas pobres. En la frontera, se encontrarían grupos de mulatos y de pardos junto a cierto aporte migratorio del norte y algún "infiel" de la pampa, según se desprende de los registros censales.

Desde la segunda mitad del siglo XVIII surgen nuevos controles del poder que acentúan aún más la diferenciación social existente. En la frontera, específicamente junto a la nueva política territorial de dominio, se da una revalorización del espacio rural junto a una mayor atención a la producción ganadera por parte de los propietarios. Esta demandaba una mayor ocupación de mano de obra y la necesidad de fijar los "vagos" a una residencia bajo control de las familias propietarias. ${ }^{54}$

A fines del período colonial, a Francisco Ticera -residente del paraje Saucesito en Tegua, jurisdicción de la Villa-, se le impuso la pena de destierro. El Alcalde de la Villa le solicitó "que salga con toda su familia de esta jurisdicción”. Ticera no era propietario de tierras pero se dedicaba a la producción de ganado para el autoconsumo familiar y se tornaba un sospechoso para quienes controlaban el espacio rural. Aunque los testigos coincidían en su honradez, la sospecha estaba en el capital ganadero de Ticera y en la ocupación de tierras que no le pertenecían.

Según un testigo presentado en el expediente,

se le conocia para su manutencion un rebaño de cabras que pueden andar cerca de cien entre chicas y grandes, y asimismo que también tiene un rebaño de ovejas dentro otras que tiene cuidando ajenas, apenas que regular, que seran unas pocas más de cincuenta y que asímesmo le conoce tres o cuatro lecheras y unas tres manaditas de yeguas, como así unos pocos caballos que pueden ser los que el conoce de ocho a diez. Y siendo preguntado si savia o le constaba a este, se mantenia o no con onradez, respondió el declarante que ni le constaba ni había oído a nadie que este proceder hubiera sido perjudicante a naides.

\footnotetext{
${ }^{54}$ La relación entre el fenómeno de la vagancia y el delito llevaría al Cabildo a principios del siglo XVIII a plantear la necesidad de erradicar los vagos que vivían sin trabajar en la ciudad y se los responsabiliza de los robos. Ese grupo de marginales estaba compuesto no solo por mestizos sino también por españoles pobres. Aníbal Arcondo, El ocaso de una sociedad estamental. Córdoba entre 1700 y 1760, Córdoba, Universidad Nacional de Córdoba, 1992, p.214. Tema también planteado por Emiliano Endrek, El mestizaje en el Tucumán: Siglo XVIII. Demografía Comparada, Córdoba, 1967, y para la región específicamente por M. E. Rustán, De perjudiciales a pobladores de la frontera. Poblamiento de la frontera sur de la gobernación Intendencia de Córdoba a fines del siglo XVIII, Córdoba, Ferreyra Ed., 2005.
} 
Es de aclarar que los Ticera eran de procedencia de Córdoba y según se registran en 1813, continuaban habitando el Saucecito, pero esa vez en relación de dependencia, es decir como peones. Fue por entonces Don Francisco Xavier Molina, propietario de la Estancia de Tegua, quien le había solicitado que saliera con su familia del vecindario. 55

Otros casos se localizaban en el Pueblo de San Bernardo y estaban anotados como labradores. Estos podrían estar vinculados al destierro que años antes se le practicara a Francisco Ticera y también se habrían trasladado a la frontera junto a su familia.

\section{Familias "bagamundas"}

En el censo de 1778 se registran varias familias caracterizadas como vagabundas. En la sierras de Río Arriba, por ejemplo, vivía el indio Lorenzo Balmaceda junto a su mujer Cathalina Acosta. También india, con dos hijos pequeños, junto con sus hermanos Lorenso Miguel, Juan, María e Juana, "thodos estos son una familia Los mas estrafalarios y Bagamundos qe cubre el sol”, 56 relataba el censista. Se anotaba también al indio Pascual Ribarola, junto a 14 personas: del mayor de 54 años hasta el menor, una criatura de 8 meses. "Thodos Bagamundos Naturales de la Punta de San Luis". ${ }^{57}$ En otras casas, además de mencionar el grupo familiar, se registran los hombres "bagamundos". 58 Se suma a esa lista a Damiam Lescano "Vagamundo Natural de Vuenos ayres, que encabeza a toda una família Vagamunda".59

\footnotetext{
55 AHMrC, Documentos del Extinto Cabildo. El Saucesito. Se le impone la pena de destierro a Francisco Ticera. Reproducido en Daila Prado y M. A. Tréspidi, Cabildo y Justicia: Expedientes emanados del Cabildo de la Villa de la Concepción del Río Cuarto y su jurisdicción (1798-1823), Río Cuarto, UniRio, 2009, pp.135-143.

${ }^{56}$ Censo 1778. Casa n. ${ }^{\circ}$ 234. M. R. Carbonari, Censo 1778. Partido de Río Cuarto, p.56.

${ }^{57}$ Casa n. ${ }^{\circ}$ 268. M. R. Carbonari, Censo 1778. Partido de Río Cuarto, p.63.

58 Casa n. ${ }^{\circ}$ 297, 298 e 355. M. R. Carbonari, Censo 1778. Partido de Río Cuarto, pp.67 y 77.

${ }^{59}$ Casa n. ${ }^{\circ} 375$. Casa de Ujenio, Esclavo de Patricio chenique, junto a su mujer, mulata e cuatro hijos. M. R. Carbonari, Censo 1778. Partido de Río Cuarto, p.82.
}

Dossier: Cuestionando las fuentes de archivos: padrones de población, familias y sociedades coloniales en Iberoamérica, ss. XVIII-XIX 
En la llanura vivía Nicolás Garnica, junto a su mujer e hijo: "Bagamundo qe no tien más oficio que robar ni tienen casa, sino adonde les coxe la noche". ${ }^{60} \mathrm{Tam}-$ bién al final del registro del Fuerte Punta del Sauce se anotan a 5 individuos "Vagamundos y de malas propiedades". ${ }^{61}$

El registro de la existencia de estas familias "vagamundas" por la campaña muestra, por una parte, la movilidad espacial de las mismas en procura de su sustento y, por otra, la preocupación de los propietarios de lo que podría ser una amenaza al no encontrarse en relación de dependencia.

\section{El control de la Campaña por las familias propietarias}

La vagancia en la campaña perjudicaba fundamentalmente a los hacendados propietarios. Los robos de ganados eran considerados los delitos más comunes y las familias propietarias reclamaban a las autoridades la represión a los ladrones. El cuadro considerado delictivo fue también la preocupación del Cabildo de la Villa

[...] poblándose de este modo los campo de salteadores y bandidos que son un peligro para los pasajeros y transeúntes y tienen la osadía de atropellar las causas desamparadas de los vecinos [...] violentan mujeres teniéndolas por largo tiempo en los bosques, haciendo dificilisima su capción. ${ }^{62}$

Fue el hacendado Alexandro de Echenique, ${ }^{63}$ vecino y propietario de Piedra Blanca, en San Bartolome (Rio Arriba), como Alcalde de la Santa Hermandad, ${ }^{64}$ quien pro-

\footnotetext{
${ }^{60}$ Casa n. ${ }^{\circ} 444$. M. R. Carbonari, Censo 1778. Partido de Río Cuarto, p.95.

61 Casa n. ${ }^{\circ}$ 509. M. R. Carbonari, Censo 1778. Partido de Río Cuarto, p.107.

62 Acta capitular 6-1-1806. Actas capitulares de la Villa de la Concepción de Rio Cuarto, (17891824), p.183.

63 Juan Alexandro Echehique Urtubey era propietario de la Estancia de Piedra Blanca por herencia de su madre, siendo descendiente por $\mathrm{V}$ generación del conquistador Gerónimo Luis de Cabrera. Accede a la propiedad por herencia de parte de la antigua merced de la región. Hijo de Jerónimo Luis de Echenique y Cabrera quien había sido Maestre de Campo y también Alcalde Mayor Provincial de la Santa Hermandad. Fue Maestre de Campo, Alcalde Provincial de la Sta. Hermandad en
}

Dossier: Cuestionando las fuentes de archivos: padrones de población, familias y sociedades coloniales en Iberoamérica, ss. XVIII-XIX 
puso a las autoridades un régimen de los comercios de la campaña para reglamentar los excesos y exterminar los ladrones. Con ello se generó un expediente en la que constaban los principales vecinos ${ }^{65}$ de la región. El documento elaborado a tal efecto, expone la forma de vida de las familias del ámbito rural excluidas do la jerarquía social y legal de la época así como sus estrategias de sobrevivencia.

En el escrito Echenique argumenta que ante el temor del robo de la hacienda se proponía que se prohibiese a la "gente sospechosa natural o española, agregada, esclavos" comprar o vender sin el consentimiento de sus amos; y que las entregas de la hacienda de ganado, tanto mular, bovino o equino, debían ser realizadas en ferias o "tabladas públicas", calculando que los puestos fuesen controlados por los propios vecinos hacendados de la jurisdicción. En rio Quarto ello sería en los Corrales del Capitán don Pedro López, ${ }^{66}$ en Tegua, en la casa de don Luis Molina, ${ }^{67}$ en Tapa, en la estancia de don Jossef Benito de Acosta. ${ }^{68}$ Además de que se prohibiese

1767, 1768, 1772, 1777. A. Moyano Aliaga, Don Gerónimo Luis de Cabrera 1528-1574 Origen y Descendencia, p.133.

64 Durante el periodo Colonial la Justicia era ejercida por los Alcaldes de La Santa Hermandad, llamados también de jueces de Pedáneos. Eran vecinos de la jurisdicción nombrados por el Cabildo. Juan Garavaglia, Poder, conflicto y relaciones sociales: el Río de la Plata, XVIII-XIX, Buenos Aires, Homo Sapiens Ediciones, 1999, p.90.

65 El gobernador Intendente de Córdova proponiendas deste Tribunal varios medios para exterminar los ladrones de aquellas campañas. Archivo General de la Nación (AGN), 1789, Sección Colonia Tribunales Leg 210. Exp. 5. Reproducido por María Ester Bordese, Vagos, cuatreros y ociosos. Documentos para el estudio de la campaña del Río Cuarto (Siglo XVIII), Rio Cuarto, Centro de Investigaciones Históricas UNRC, 2008, p.41.

66 Pedro Thomas López localizado en el censo de 1778 junto a su mujer Francisca Freytes y 7 hijos, tres esclavos y cuatro agregados en la casa n. ${ }^{\circ} 68$. M. R. Carbonari, Censo 1778. Partido de Río Cuarto, p.30. Por herencia de su mujer, era propietario de parte de la estancia el Tambo quedándose con la propiedad de La Esquina. Formó parte de las familias que fueron a Poblar la Villa en 1794. Fue Regidor Fiel Ejecutor en 1799 y también Capitán de Milicias. Víctor Barrionuevo Imposti, Historia de Río Cuarto, tomo 1, Buenos Aires, TIPENC, 1986, p.72.

${ }^{67}$ José Luis de Molina Navarrete y Arias Montiel era propietario por herencia de la Estancia de Tegua, descendiente del conquistador Tristán de Tejeda. En 1778, está localizado en el Censo en la Casa n. ${ }^{\circ}$ 35. M. R. Carbonari, Censo 1778. Partido de Río Cuarto, p.21.

68 El Capitán de Milicias, José Benito Acosta, oriundo de Galicia, se había convertido en propietario de la Estancia La Tapa por herencia de su Segunda esposa María Josefa Echenique descendiente por línea paterna de los Cabrera. El Capitán Acosta en 1776 había participado de una entrada española a las pampas junto al Maestre de Campo Ventura Montoya.

Dossier: Cuestionando las fuentes de archivos: padrones de población, familias y sociedades coloniales en Iberoamérica, ss. XVIII-XIX 
también las corridas de hacienda (vaquerias) a los que no eran dueños criadores y que toda gente "libre ociosa y vagamunda que no tiene haciendas o bienes propios [...] de donde poderse mantener sea consertado asalariado"; así como no se habilitasen mesas de juego; y que cualquier traficante o comerciante que se introduzca en la jurisdicción a comprar boyadas, charqueadas de reses en arrias debían solicitar un pase. ${ }^{69}$ Lo que muestra cuán preocupante era el control por el espacio bajo dominio de los vecinos hacendados.

Los nombres de referencia en el documento son los vecinos que detentaban la propiedad antes de la fundación de la villa. Eran capitanes de milicia como Joséf Benito Acosta y Pedro Tomás López, o descendientes de conquistadores como Luis Molina Navarrete y Alexandro Echenique, cuyos espacios más significativos estaban en Tegua, Tapa y La Esquina. Es decir, espacios serranos en los que pretendían proteger a su producción y tener a la población bajo sujeción.

Según el documento, varias "familias infelices" habitantes en los bosques, quebradas y sierras, vivían de los robos de ganado y haciendo "contrayerro" o desfigurando sus marcas. ${ }^{70}$ Estos ladrones, toman las haciendas de sus vecinos para "mantener una familia de muger, hijos y algunos parientes". Uno de los problemas de la campaña era "[...] que siendo tan extensivas estas tierras [...] que [...] viben muy dispersos sus moradores y por consiguiente no pueden tener dedicación a otra labor que a la cria de algun ganado y siembra de maiz, unicos alimientos de la multitud", puesto que era gente que no se dedicaba a la agricultura y el labradío de los campos. Si bien "pueda aplicarse a los cultivos como no tienen salida sus frutos, por no reportar la benta los [...] costos de su conducción por las distancias, omiten su execución y esta imposibilidad o inopia les acarrea el baxo pensamiento de pasar la vida en holgazanería con la facilidad de tener el campo abierto para su depravado pero necesario sustento". ${ }^{71}$

Sin residencia fija, por lo que se reconoce la movilidad espacial, tal vez procurando el sustento, tal vez huyendo de los propios controles coloniales, estos moradores se pasaban "[...] de unos (partidos) a otros sin ocuparse en exercicio que

\footnotetext{
${ }^{69}$ AGN, 1789. Sección Colonia, Tribunales, leg.210, exp.5.

${ }^{70}$ AGN, 1789. Sección Colonia, Tribunales, leg.210, exp.5. ff.21v, y 53r. y v.

${ }^{71}$ AGN, 1789. Sección Colonia, Tribunales, leg.210, exp.5. f.27v.
}

Dossier: Cuestionando las fuentes de archivos: padrones de población, familias y sociedades coloniales en Iberoamérica, ss. XVIII-XIX 
sea util a la República”. La vigilancia de estas familias en distintos lugares era necesaria para el poder hegemónico preocupado por los ambulantes de la región. ¿De dónde y por qué venían? ¿Cuál era su ocupación? ¿Cuál era su destino? Eran indagaciones que preocupaban a las familias propietarias atentas a ciertas prácticas de "fieles a (sus dueños) y los sirben como esclavos pero arruinan a los besinos". ${ }^{72}$ Por eso estimaban que esos agregados "son la polilla del vecindario mas cercano como no tienen que comer y su trabajo nada les produse porque los mas del año sirben a sus Patrones por el terreno en que biben". ${ }^{73}$

Con esa lectura, los robos se presentan para los hacendados como un comportamiento naturalizado de las familias pobres: "hasta los niños y mugeres roban [...] en los chiqueros se lleban las obexas que de bacas ya no se ase juicio porque al fin andan en el campo", Generalmente viven amancebados y ocupados en la práctica del juego, tanto los "hijos de familia, esclavos y peones". ${ }^{74}$

Esa práctica, asociada al comportamiento ilícito en la campaña, mantenía cierta complicidad de algún que otro hacendado. Así, estaban los que robaban hacienda (mular y equino principalmente) y la trasladaban a otra jurisdicción para la venta, los que vivían robando todo el año para mantenerse, y los que robaban ocasionalmente a los transeúntes.

Pero también había hacendados que tenían en sus tierras "muchos inquilinos o agregados, a los que con tal que aellos les sirban en sus faenas les permitan y disimulan que vivan robando a los vecinos" y que tenían también esclavos permitiéndoles que "[...] vivan del hurto y con eso se aorran ellos de mantenerlos". Completa el panorama, de los dichos males de la campaña, los traficantes que tenían "[...] su comercio en tropas de mulas y al caminar con ellas van agregando muchos de las que pasan cercanas del camino", y los carreteros "que hacen sus traficos manteniendo sus peones a costa de las haziendas de los vecinos por donde transi$\tan .75$

\footnotetext{
72 AGN, 1789. Sección Colonia, Tribunales, leg.210, exp.5. f.29r.

${ }^{73}$ AGN, 1789. Sección Colonia, Tribunales, leg.210, exp. 5. f.21v.

${ }^{74}$ AGN, 1789. Sección Colonia, Tribunales, leg210, exp.5. f.3ov.

75 AGN, 1789. Sección Colonia, Tribunales, leg.210, exp.5, ff.38r.- 39v.
}

Dossier: Cuestionando las fuentes de archivos: padrones de población, familias y sociedades coloniales en Iberoamérica, ss. XVIII-XIX 


\section{El caso del mulato Bacilio}

En ese escenario de campaña, en la región del Río Cuarto se pudo identificar la práctica del mulato Bacilio, natural de Río Arriba, censado en 1778 en la casa de Juana Rosa Freytes junto a tres esclavos más. Este residía allí con su mujer, Josepha Bustos, india libre, tres hijas y su suegra. ${ }^{76}$ Su historia documentada en el sumario levantado por el comandante de Frontera ilustra con ciertos matices la vida de un esclavo en la frontera de Río cuarto. ${ }^{77}$ El pertenecía a Juana Rosa Freytes, posteriormente pasó a ser propiedad del Capitán don Joseph Freytes. ${ }^{78}$ Pero, según testimonia el Coronel Acosta, acostumbrado al "libertinaje que había gozado [...] años en poder de una pobre señora sola le hizo fuga imediantamente al nuebo amo llendo a refugiarse procurando el amparo de don Patricio Echenique". ${ }^{79}$

Para 1786, el esclavo mulato Bacilio era el capataz de la estancia La Tapia, propiedad de Patricio de Echenique..$^{80}$ El 17 de julio de 1786, el Comandante de Fronteras Coronel don Joseph Benito Acosta, ${ }^{81}$ presenta una denuncia contra el esclavo Bacilio por los excesos de robo y pérdida de respeto. Por ser -según el propio Coronel- mulato dañino y perjudisial en las hacienda de Campo de aquel besindario del Tambo donde fue criado", dedicado a vender "quanto animal ajeno se le proporsionaba robar del campo", situación de la cual su amo tenía conocimiento, si bien "dandole facultades a correr enlsar y matar ganados en el campo como lo está praticando de tres años a esta parte con el pretesto de tener ganado cimarrón”. Al parecer don Patricio de Echenique había dejado al mulato Bacilio en

\footnotetext{
${ }^{76}$ Censo 1778. Casa n. ${ }^{\circ}$ 235. M. R. Carbonari, Censo 1778. Partido de Río Cuarto.

77 AHPC, Crimen. 1786, leg.43. Exp.9.

${ }^{78}$ Sobrino de la citada. El capitán lo compra en el servicio de "sacar mulas de la Jurisdicción de Buenos Aires”, pero en el camino huye y pide refugio a Patricio Echehique.

${ }^{79}$ AHPC, Crimen. 1786, leg.43, exp.9. Juan Patricio Echenique y Garay (1742-1810).

80 A. Moyano Aliaga, Don Gerónimo Luis de Cabrera 1528-1574 Origen y Descendencia, p.121.

81 José Benito Acosta, Natural de Galicia, casado en Córdoba en primeras nupcias con Ipólita Garay y Molina, en el año 1765 sin sucesión, y en segundas nupcias con María Josefa Echenique, también sin sucesión. hija de Francisco Xavier Echenique y del Barco, y de Rosa Tablada. Muere en el año 1800 , residente en La Tapa.
}

Dossier: Cuestionando las fuentes de archivos: padrones de población, familias y sociedades coloniales en Iberoamérica, ss. XVIII-XIX 
la Estancia Las Tapias, aunque él mismo fuese víctima de robos que el propio Bacilio cometía. Por tres años y para mantenerse, según proporciona el testimonio de Pedro Joseph Garay, "le dejaba una majada de obejas y todo el ganado alzado y simarron que tenia en la Cierra".

La estancia de Juan Patricio Echenique (Las Tapias) lindaba con la del coronel Acosta (La Tapa), por lo que éste consideraba que el mulato hacia las corridas en el campo "sin reparar que siempre habido ganado de mi marca intripulado con el sullo y que para hazaer semejante correrias avia ser con asistencia de mi mayordomo o capatases y no pribadamente".

Bacilio fue remitido a la cárcel, y después de 5 meses recuperó la libertad. El coronel levantó la querella y don Patricio se comprometió al traslado del mulato a la Estancia de los Molinos, en río Segundo. Se observa en este caso, un conflicto entre hacendados parientes por el control del ganado cimarrón, pero también la relativa libertad del esclavo en la campaña.

\section{Algunas reflexiones finales}

El presente escrito se constituye en un esfuerzo por tratar de reconocer la funcionalidad del espacio regional en el mundo colonial e identificar las características que asume su población en la región de frontera. De allí la importancia de los registros censales. Busca comprender, por otro lado, cómo dentro de ese contexto los sujetos sociales no estaban enteramente determinados por las estructuras y condiciones económicas, sino que se articulaban de manera activa a la configuración de la estructura social en la que vivían siguiendo diversas estrategias familiares.

La perspectiva permite también hacer foco en los tipos de relaciones que los grupos establecen y el lugar que ocupan en esa sociedad. Ello permite exponer la compleja trama de relaciones que operan entre las estructuras globales y las praxis de los sujetos; entre las condiciones de vida particulares y las relaciones de producción y de dominación existentes en el período.

A partir de registros censales y de los estudios de población en la región cotejados con otras fuentes y datos dispersos, es posible rescatar no sólo lo singular,

Dossier: Cuestionando las fuentes de archivos: padrones de población, familias y sociedades coloniales en Iberoamérica, ss. XVIII-XIX 
una trayectoria familiar por ejemplo, sino también explicar cómo funciona y se reproduce una sociedad en un determinado contexto económico-social. La perspectiva, más allá de lo que implica en cuanto renovación teórica e historiográfica, ofrece al campo intelectual de los historiadores nuevas oportunidades para pensar desde los distintos espacios las relaciones que el todo y las partes tejen y los protagonismos que explican sus dinámicas.

En ese marco, si los grupos de elites resultan más identificables que otros, también es posible trabajar sobre los grupos sociales o las familias no propietarias. En la medida que los registros censales ofrecen poca información al respecto, otras fuentes o registros casuales, como los procesos de la justicia, relatos de la autoridad, reglamentaciones del gobierno o informes de los hacendados que buscaban el control, agregan otra información que refiere a la existencia de esos grupos sociales habitantes del medio rural.

En éste, el texto se ocupa de mostrar a ese cuadro sociodemográfico que incluye a hacendados propietarios, comerciantes y militares, pero también a pequeños campesinos y productores independientes, así como a otros considerados marginales que tenían sus propias estrategias de reproducción. Con lo visto, si el desacato a las normas implicaba el accionar de los denunciantes, también los denunciados seguían prácticas que frente a las pautas culturales impuestas buscaban su propia acomodación.

Así, es posible reconstruir las estrategias de dominio de los herederos de conquistadores y pobladores propietarios constituidos en vecinos de la región; pero también identificar formas de resistencia y acomodación de la población india sometida. La que sería transformada en mano de obra junto a sus herederos - o quedarían al margen de la sociedad colonial instituida- y la de otros sujetos que en condición de esclavos fueron obligados a habitar ese espacio y que también dejaron su rastros en los registros de la época. 


\section{Bibliografía}

\section{Fuentes primarias:}

Archivo General de la Nación (AGN), Sección Colonia

Archivo Histórico de la Municipalidad de Río Cuarto (AHMRC), Periodo Colonial, Documentos del Extinto Cabildo.

Archivo Histórico de Mendoza (AHM) Época Colonial, Sección Gobierno,

Archivo Histórico de la Provincia de Córdoba (AHPC), Gobierno, Escribanía,

Actas capitulares de la Villa de la Concepción de Rio Cuarto, (1789-1824), Buenos Aires, Academia Nacional de Historia, 1947.

Amigorena, Francisco, "Descripción de los caminos, pueblos, lugares que hay desde la ciudad de Buenos Aires ala de Mendoza, en el mismo reino", en Cuadernos de Historia Regional vol.Iv, Universidad Nacional de Luján, 1988 [1787].

\section{Fuentes secundarias:}

Arcondo, Aníbal, El ocaso de una sociedad estamental. Córdoba entre 1700 y 1760, Córdoba, Universidad Nacional de Córdoba, 1992.

Arcondo, Anibal, La población de Córdoba en 1813, Córdoba, Instituto de Economía y Finanzas, 1995.

Assadourian, Carlos S., Sistema de la economía colonial. Mercado Interno, regiones y espacio económico, México, Nueva Imagen, 1982.

Bandieri, Susana, "La posibilidad operativa de la construcción histórica regional o como contribuir a una historia nacional más complejizada", en Sandra Fernandez y Gabriela Dalla Corte (comps.), Lugares para la Historia. Espacio, Historia Regional e Historia Local en los Estudios Contemporáneos, Rosario, UNR, 2001.

Dossier: Cuestionando las fuentes de archivos: padrones de población, familias y sociedades coloniales en Iberoamérica, ss. XVIII-XIX 
Barrionuevo Imposti, Víctor, Historia de Río Cuarto, tomo 1, Buenos Aires, TIPENC, 1986.

Bordese, María Ester, Vagos, cuatreros y ociosos. Documentos para el estudio de la campaña del Río Cuarto (Siglo XVIII), Rio Cuarto, Centro de Investigaciones Históricas UNRC, 2008.

Bordese, María Ester, Mitre, Ana Belén y Germanetto, Gabriel, "Poder y red familiar en la Villa de la concepción entre 1798- 1820 (Un estudio de caso)", en Cronía vol.4, n. ${ }^{\circ}$ 2, Río Cuarto, UNRC, 2001-2002.

Carbonari, María R., "Población y Espacio. Fines del Siglo XVIII", en Cronía vol.2, n. ${ }^{\circ}$ 2, Río Cuarto UNRC, 1998.

Carbonari, María R., "De quién es ese espacio: la construcción de la frontera sur", en Revista Memoria Latinoamericana n. ${ }^{\circ}$ 2, Río Cuarto UNRC, 1998.

Carbonari, María R., Censo 1778. Partido de Río Cuarto, Río Cuarto, UNRC, 2003.

Carbonari, María R., "Los aportes historiográficos y los estudios de la familia en una región de frontera: Río cuarto a fines del siglo XVIII e inicios del XIX", en Revista Dos Puntas n. ${ }^{\circ}$, La Serena, San Juan UNRSJ-u, 2009 .

Carbonari, María R., "De cómo explicar la región sin perderse en el intento. Repasando y repensando la Historia Regional", en História Unisinos vol.13, n. ${ }^{\circ}$, 2009, pp.19-34.

Carbonari, María R., "La Revolución de Mayo" en una Villa Real de reciente conformación. Diálogo entre lo micro y lo macro", en Miguel Angel Tréspidi y Daila Prado (comp.), Bicentenario, memorias y proyecciones Río Cuarto, UNRC, 2010.

Carbonari, María Rosa y Magoia, Rosana, "Prácticas mercantiles y familias campesinas en la región de Río Cuarto a inicios del siglo XIX", en Cronia, Río Cuarto, UNRC, 2002.

Carbonari, María R. y Baggini, Iván, Población y Familias en la región del Río Cuarto. Fines del siglo XVIII, Río Cuarto, Junta de Historia de la Municipalidad de Río Cuarto, 2004. 
Carbonari, María Rosa y José Cocilovo, El censo de 1778 en la región del Río Cuarto (Córdoba, Argentina). Fundación Universidad Nacional de Río Cuarto 2004.

Chacón Jiménez, Francisco, "Familias y sociedad. Reflexión teórica sobre problemas prácticos", en Perfiles de la Cultura Cubana n. ${ }^{\circ} 8$, La Habana, Revista del Instituto Cubano de Investigación Cultural Juan Merinello, 2012.

Celton, Dora, La población de la Provincia de Córdoba a fines del siglo XVIII, Buenos Aires, Academia Nacional de Historia, 1993.

Celton, Dora, Ciudad y campaña en la Córdoba colonial, Córdoba, Junta Provincial de Historia de Córdoba. 1996.

D’Andrea, Ulises y B. Nores, Alpa Corral. Sus orígenes y su historia, Río Cuarto, Córdoba, 2004.

Endrek, Emiliano, "El mestizaje en Córdoba. Siglo XVIII y principios del XIX", en Cuadernos de Historia n. ${ }^{\circ}$ XXXII, Córdoba, UNC, 1966.

Endrek, Emiliano, El mestizaje en el Tucumán: Siglo XVIII. Demografía Comparada, Córdoba, 1967.

Falco, Nancy y Negro, Susana, "Don Bruno Malbrán y Muñoz y su incorporación a la red de familias de la elite de la Villa de la Concepción”, Córdoba, UnRC, 2009. Inédito.

Fassi, Juan B., "El antiguo Curato de Río Cuarto y la Nueva Diócesis", en El Heraldo de Reducción n. ${ }^{\circ} 11$. Córdoba, 1935.

Fourcade, Adriana, Una Villa de Frontera. Estudio de la población de la Villa de la Concepción del Río Cuarto (180o - 1850), Río Cuarto, Ed. Icala, 1991.

Garavaglia, Juan Carlos. "Los textiles de la tierra en el contexto colonial rioplatense: ¿una revolución industrial fallida?”, en Anuarios IEHS n. ${ }^{\circ}$, Tandil, Universidad Nacional del Centro de la Provincia de Buenos Aires, 1986.

Garavaglia, Juan Poder, conflicto y relaciones sociales: el Río de la Plata, XVIII-XIX, Buenos Aires, Homo Sapiens Ediciones, 1999. 
Lascano Colodrero, Arturo Germán de, Linajes de la Gobernación del Tucumán. Los de Córdoba, tomos 1, 2 y 3, Córdoba, Ed. Biffignandi, 1936-1960.

Gramsci, Antonio, Cuaderno de Cárcel, tomo II, México, Ediciones Era, 1981.

Mayol Laferrère, Carlos, "Linajes fundadores de la Villa de la Concepción del Río Cuarto. Acosta", en Boletín del Instituto de Estudios Históricos. Lorenzo Suárez de Figueroa n. ${ }^{\circ}$ I, 1975.

Mayol Laferrère, Carlos, "Noticias Histórico-Biográficas de los Primeros Pobladores de la Villa de la Concepción del Río Cuarto", en Boletín del Instituto de Estudios Históricos Lorenzo Suárez de Figueroa, n. ${ }^{\circ}$, 1980.

Mayol Laferrere, Carlos, "La primera Colonización del Río Cuarto”, en Diario Puntal, Río Cuarto, enero 11 de 1981.

Mayol Laferrere, Carlos, El Cabildo y los cabildantes de la Villa de la Concepción del Río Cuarto. 1798-1824, Río Cuarto, UniRIO, 2014.

Metcalf, Alida, "La familia y la sociedad rural en Sao Paulo: Santana de Parnaíba, 1750-1850", en Pilar Gonzalbo Aizpuru y Cecilia Rabell (comps.), La familia en el mundo iberoamericano, México, UNAM, 1994.

Montes, Aníbal, "Historia Antigua de la ciudad de Río Cuarto", en Revista de la Universidad Nacional de Córdoba vol.XL, ${ }^{\circ}{ }^{\circ}$, Córdoba, Universidad Nacional de Córdoba, 1953.

Moyano Aliaga, Alejandro, Don Gerónimo Luis de Cabrera 1528-1574 Origen y Descendencia, Córdoba, Centro de Estudios Genealógico de Córdoba, 2003.

Prado, Daila y Tréspidi, M. A., Cabildo y Justicia: Expedientes emanados del Cabildo de la Villa de la Concepción del Río Cuarto y su jurisdicción (17981823), Río Cuarto, UniRio, 2009.

Rustán, M. E., De perjudiciales a pobladores de la frontera. Poblamiento de la frontera sur de la gobernación Intendencia de Córdoba a fines del siglo XVIII, Córdoba, Ferreyra Ed., 2005.

Sobre Monte, Rafael, “Noticias Sobre la Intendencia de Córdoba del Tucumán”, en La Revista de Buenos Aires tomo IV, n. ${ }^{\circ}$ 24, Buenos Aires, 1861 [1788].

Dossier: Cuestionando las fuentes de archivos: padrones de población, familias y sociedades coloniales en Iberoamérica, ss. XVIII-XIX 
Salinas, René e Goicovic, Igor, "Familia y Reproducción Social. Chile en el Siglo XVIII", en Julio Retamal Avila (ed.), Estudios Coloniales vol.I, Santiago, Universidad Andrés Bello, 2000.

Tamagnini, Marcela y Pérez Zabala, Graciana, "Dinámica territorial y poblacional en el Virreinato del Río de la Plata: indígenas y cristianos en la frontera sur de la gobernación intendencia de Córdoba del Tucumán, 1779-1804", en Fronteras de la Historia vol.17, n. ${ }^{\circ}$, Bogotá, ICANH, 2012, pp. 195-225.

Valdano, Silvia, Carbonari, María R. y Cocilovo, José A., La población de 1813 en la región del Río Cuarto (Córdoba, Argentina), Río Cuarto, UNRC, 2009.

Wagner, Daniela, La región del Río Cuarto. Una frontera ganadera (fines del siglo XVIII y comienzos del XIX), Río Cuarto, UNRC, 1997. Inédito.

Zorroaquin Becu, Ricardo, La organización política argentina en el período hispánico, Buenos Aires, Ed. Perrot, 1967.

Zamora y Coronado, José María, Biblioteca de Legislación ultramarina: En forma de diccionario alfabético tomo 6, Madrid, Imprenta de J. Martín Alegría, 1846 . 